Article

\title{
What Is Urban after All? A Critical Review of Measuring and Mapping Urban Typologies in Portugal
}

\author{
Cristina Henriques ${ }^{1, * \mathbb{D}}$, Alexandre Domingues ${ }^{2}$ and Margarida Pereira ${ }^{3}$ \\ 1 CIAUD, Faculdade de Arquitetura, Universidade de Lisboa, Rua Sá Nogueira, Polo Universitário, \\ Alto da Ajuda, 1349-055 Lisboa, Portugal \\ 2 Comissão de Coordenação e Desenvolvimento Regional do Algarve, Praça da Liberdade, 2, 8000-164 Faro, \\ Portugal; adomingues@ccdr-alg.pt \\ 3 CICS.NOVA Interdisciplinary Centre of Social Sciences, Faculty of Social Sciences and \\ Humanities (NOVA-FCSH), Universidade NOVA de Lisboa, 1069-061 Lisboa, Portugal; \\ ma.pereira@fcsh.unl.pt \\ * Correspondence: cdh@fa.ulisboa.pt
}

Received: 5 September 2020; Accepted: 22 October 2020; Published: 26 October 2020

\begin{abstract}
The concept of urban area is complex and has been discussed for many years by several authors and organisations through different perspectives and methodological approaches. For administrative and comparison purposes statistical institutions, both at the national and international levels, classify territories according to a certain degree of urbanisation defining typologies from which indicators and certain public policies are applied. The purpose of this study is to discuss the relevance and suitability of different urban typologies. Through mapping and measuring the data of official documents, the urban dimension of Mainland Portuguese territory is discussed and its usefulness concerning the allocation of resources for promoting territorial cohesion is stressed. Results show the inadequacy of these classifications to inform planning actions, decision making, and to promote territorial policies. It also provides evidence of inaccuracies that distort the reading of the territorial reality of the case study.
\end{abstract}

Keywords: urban typologies; degree of urbanisation; parish classification; urban areas; urban mapping; urban measurement

\section{Introduction}

The urbanisation of the population is a phenomenon on a global scale, with a tendency to increase in the coming decade [1,2]. More than half $(55 \%)$ of the world's population lived in urban areas in 2018 (30\% in 1950), and this is projected to reach $68 \%$ by 2050 [3]. "The pace of change in Europe will likely be slower, with the share of the population living in urban areas projected to rise to just over $80 \%$ by 2050" [4] (p. 9). Urbanisation processes and associated urban areas have different levels between large geographic regions [5], and very different characteristics between the global North and the global South [6]. In such a different context, it is inevitable that the concept has led to various understandings, causing distortions of realities and inherent interpretive errors.

The concept of "urban area" implies the combination of multiple attributes: minimal population size and population density [7], areas mostly built-up, although with different morphological structures (compact, distended, fragmented, diffuse), with diverse urban land uses [8], with basic infrastructures inherent to urbanisation (road network, water supply network, electricity network, basic sanitation network, urban solid waste network), economic activities centred on the secondary and/or tertiary sectors, and access to diversified services (education, health, justice, culture, leisure, sport ... ). 
These apparently objective characteristics are very differentiated, influenced by national development and urban policies, the population size of each country and its urban system.

The concept of urban area is also associated with the dichotomous division between urban and rural areas [9]. However, in heavily urbanised contexts (urban agglomerations, metropolitan areas, urban conurbations) the limits of the urban are increasingly diffuse, leading many authors to argue for a peri-/para-urban area, where urban and rural uses intertwine in different forms and intensities [10,11]. However, this third category of space increases the complexity of differentiation, given the difficulty of specifying the limits of occupational patterns of "hybrid occupations".

Such a complex concept and the methodologies for its territorial delimitation have been discussed both from an academic perspective, through various subject areas and interdisciplinary fields, or from institutional and professional practice approaches.

As regards the academic perspective, the authors of [12] provide an overview on the theorising of the urban since the Chicago School of Sociology, going through the Lefebvre three-dimensional approach to space [13], stressing its emergent role on sustainable development, and focusing on the more recent concept of cities as being a complex adaptive system $[12,14,15]$. The need for a transdisciplinary perspective to understand the urban phenomena is underlined and supported by several other authors over time [16,17].

On the other hand, practitioners and institutions are often tempted to classify places as urban or rural through dichotomising the concept of urban for practical uses [18]. The exercise of constructing a classification is fundamental for an advanced conceptualisation of complex phenomena [19]. However, many reports highlight the difficulties in establishing an approach adjusted to the heterogeneity of the definition in different countries [20-23] and in the selection of determinant indicators [24]. Classification by administrative boundaries is widely adopted by census agencies and used for comparison purposes, but its inadequacy has been widely criticised from several perspectives for its ephemeral character (boundaries can change by decree overnight) [24]; for not being restricted to urban occupation (it may include vast rural areas) [25-27]; and, related to this last issue, for affecting data collection [28] and analysis (when assuming census tracks as the smallest homogeneous area) [7]. In this respect, the modifiable areal unit problem (MAUP), first studied by Gehlke and Biehl [29], and later by Openshaw [30], addresses the discussion of this paper concerning the translation of the urban concept applied to administrative boundaries to the reality of the territory.

Spatial approaches as opposed to administrative units have been used mainly from satellite and other aerial imagery (e.g., land cover datasets, night time lights) [27,31-33]. The operationalisation of the concept of urban form through the implementation of a methodology used to delimit urban areas adjusted to Mainland Portugal, based on a European technical procedure for delimiting Urban Morphological Zones from the reclassification of the Corine Land Cover nomenclature, is an example of extending the pertinence of this approach to urban planning [34].

The urban policy uses of a certain urban concept, either by dichotomising the definition, through setting determinant indicators such as population size and population density, or through spatial approaches, are common and reflect an empirical need for decision making. Reflection on the need to define "the urban" as carried out by Sayer in 1984, leads to the main issue of this paper in the sense that "the adequacy of our definitions and concepts (...) has crucial effect on the success of the actions which they inform ..." " [35] (p. 280).

Statistics from international organisations (UN, OECD, Eurostat) and national statistics specify the concepts that support the study of this reality, which is essential for defining public policies that are more efficient and adjusted to reality. In Portugal, in the absence of a harmonised methodology for the definition of urban areas and, therefore, of a database with the delimitation of urban boundaries [36], the classification of land as urban or rural, either for land use planning goals or for statistical purposes, has been regulated by several legal documents:

1. Regarding planning issues, the General Directorate for Territory Development produced the Land Use Regime Map-CRUS (Carta do Regime do Uso do Solo)—providing harmonised information 
from the maps of the Municipal Master Plans, namely the urban perimeters defined in these territorial management instruments. Since this was obtained from the compatibilization of the different land use classes of the various master plans, it can be used for statistical purposes and for the evaluation of public policies.

2. The Land Use and Land Cover Map—COS (Carta de Uso e Ocupação do Solo)—is another document from the General Directorate for Territory Development, obtained by aerial photo interpretation of orthophotos, and nowadays an open data source of information on the geographical distribution of human activity and the corresponding socio-economic function. It is used by researchers and decision makers, particularly municipalities, to spatially perceive the changes and its impacts on the territory, and therefore for land use planning and management actions.

3. Statistics Portugal created, the concept of a "statistical city" which, in most cases, corresponds to the adjustment of the urban perimeter defined by legal land use instruments (such as CRUS) and through consultation with municipal councils, to the statistical subsection [37] used by this institution. In parallel, a typology of urban areas-TIPAU (Tipologia das Áreas Urbanas)—is also established. According to this institution, TIPAU is the nomenclature for the degree of urbanisation, classifying parishes-LAU2 (Local Administrative Units level 2) [38] —into "Predominantly urban areas" (APU), "Medium urban areas" (AMU) and "Predominantly rural areas" (APR) [39]. This classification is a tool for statistical purposes, but it also had repercussions on the allocation of public funds and resources until 2018, as established by Law No. 73/2013 (Article 38). More recently, this law was repealed and TIPAU was removed as a criterion for the distribution of parish financing funds (Law No. 51/2018).

4. At the European level, EUROSTAT provides a classification on the degree of urbanisation—DEGURBA [40]—classifying parishes (LAU2) into three types of areas: Code 1—cities (densely populated areas), Code 2-towns and suburbs (intermediate density areas), Code 3-rural areas (thinly populated areas) [22]. Portuguese parishes are therefore classified accordingly.

In short, the criteria for delimitation of urban areas are different according to the institution and the purpose for which they are intended, also giving rise to a distinct "map" of the urban, both in Portugal and in many other countries (Figure 1).

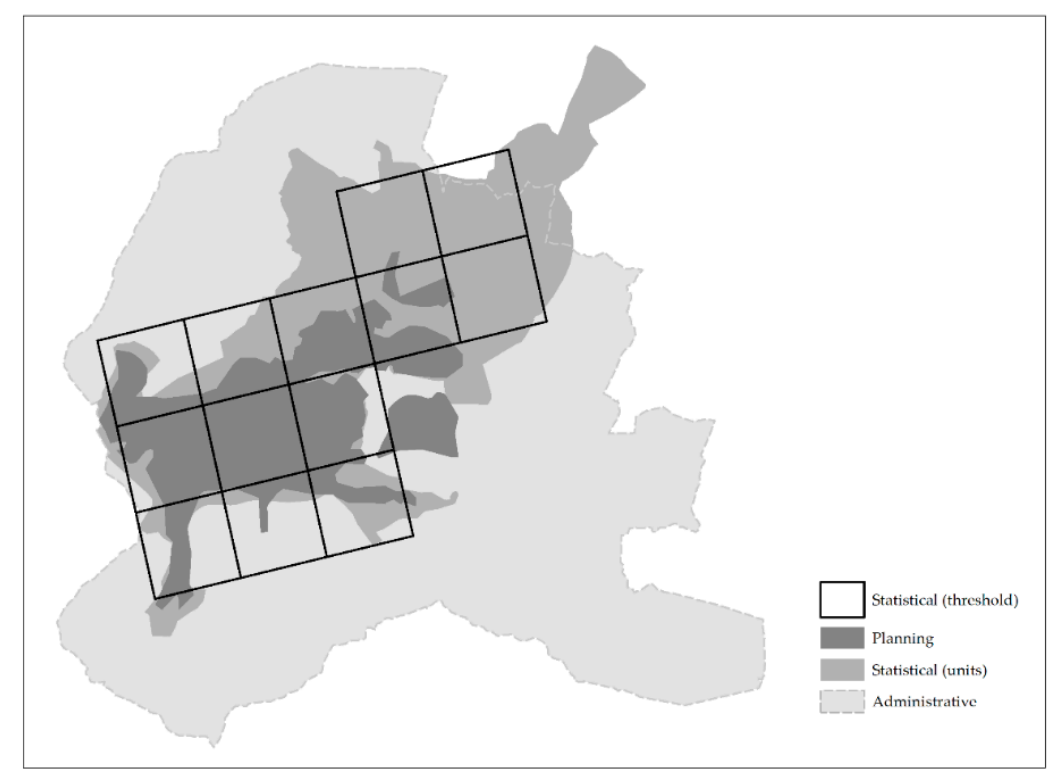

Figure 1. What is urban after all? Schematic representation of the different approaches classifying the territory as urban.

The focus of this paper is a discussion of the relevance and suitability of the different urban typologies used in official documents to provide information on the urban condition of the territory and to national and internationally compare the degree of urbanisation. Although several authors 
discussed the concept of the urban and criticised the classification used by statistical agencies, this paper aims to fill the gap in the literature concerning the comparison of the different classifications of the territory as urban by official authorities, and their disparities and inconsistencies. The findings allow decision makers, planners, and researchers to understand the constraints when using these datasets. Therefore, the main scientific contribution of the research lies in demonstrating, through mapping and measuring, the inadequacy of these classifications for informing planning actions and decision making, and for promoting territorial cohesion policies. It also provides evidence of inaccuracies that distort the reading of the territorial reality.

Research motivation is twofold. The first results from the participation of the authors of the present paper on several studies for the Portuguese public administration concerning the administrative reorganisation of the territory. An empirical perception of the contradictions regarding the definition of urban typologies brought about the need for a deeper study of the territorial classification. The second motivation comes from the need to highlight the inadequacies of the urban classifications. Several technical and scientific studies (land use planning and policy making [41,42], social-economic [43], environmental and health [44-46], among others) make use of these classifications as an assumption for starting point, and for sample selection, and the authors think that a careful study and a clarification must be made to avoid distortions and misunderstandings.

The paper is organised into five parts. The introductory part provides an overview of the different perspectives of the concept of "urban area" referring to the difficulties and solutions adopted by official institutions when classifying the territory according to its degree of urbanisation. The aim of the research is also presented here. The second part contains the workflow of the research and presents the materials used for the research. The assumptions of the official classifications of the Portuguese territory concerning the urban dimension are explained and the territorial expression of the urban dimension of these classifications is mapped here. The last three parts of the paper present the results of the analysis of these classifications, the discussion regarding their suitability and some conclusions.

\section{Materials and Methods}

\subsection{Methodological Approach}

The classification of the territory as urban, either from a morphological approach for spatial or territorial planning or from an administrative perspective, was discussed through an extensive literature review that stresses the advantages and the weaknesses of both approaches.

Using the Portuguese case and data provided by official authorities that support the different classifications, the territorial extension of the urban was mapped accordingly. Comparisons were made, first by comparing the classifications under a morphological approach (CRUS and COS) and later the classifications under an administrative and statistical approach. The different criteria used by the two statistical authorities to establish the typologies was studied based on the assumptions described in the Data Sources section.

The differences in terms of area classified as urban and its distribution across the territory were highlighted.

A detailed analysis was carried out, combining demographic and socio-economic indicators to assess the classifications taking into consideration the reality of the territory. A set of relevant examples were selected to show inadequacies either from the point of view of the territorial reality or its statistical coherence.

Finally, a reflection was made on the consequences of using typologies of the urban in the definition of territorial policies and in their use for statistical international comparisons. Figure 2 summarises the different methodological stages of the study. 


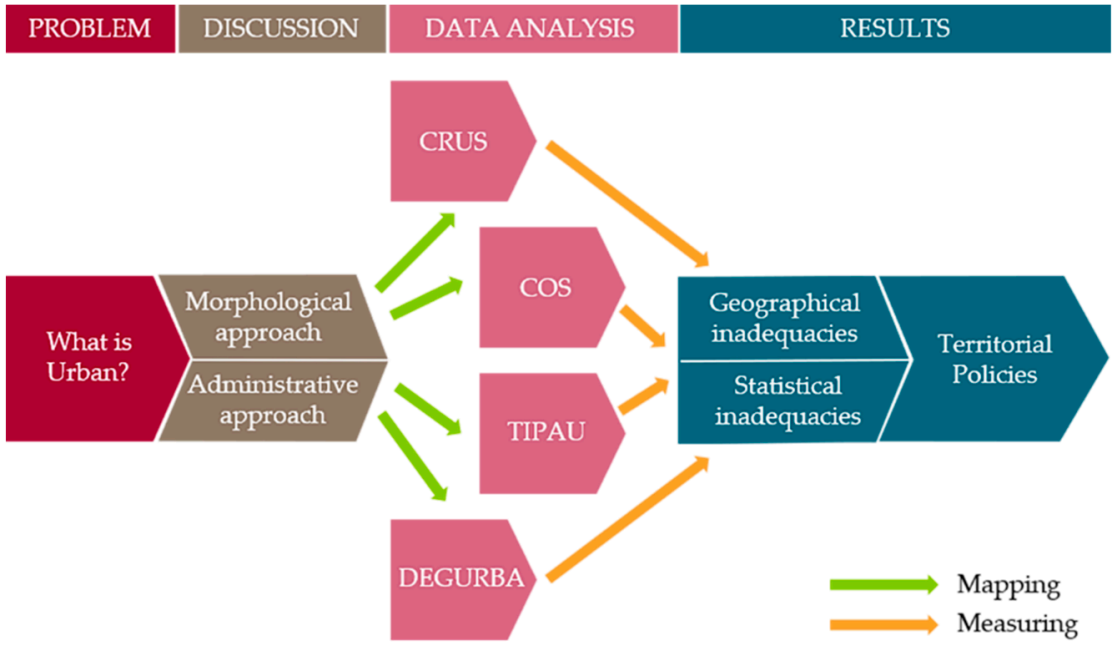

Figure 2. Methodological research stages (workflow design based on [47]).

\subsection{Data Sources}

The materials used to map, measure, and discuss the urban dimension of Mainland Portuguese territory (Figure 3) and their usefulness for the allocation of resources for promoting territorial cohesion, are the official documents provided either by the General Directorate for Territory Development, Statistics Portugal or Eurostat, as stated above (COS, CRUS, TIPAU, DEGURBA). These documents are not all semantically comparable: while COS and CRUS use morphological classifications for the territory, i.e., based on the extent and continuity of the built-up areas (existing and proposed), TIPAU and DEGURBA apply typologies to administrative areas and have statistical purposes. However, all these documents can provide data on the urban dimension and are instruments used for statistics, spatial planning and territorial policies.

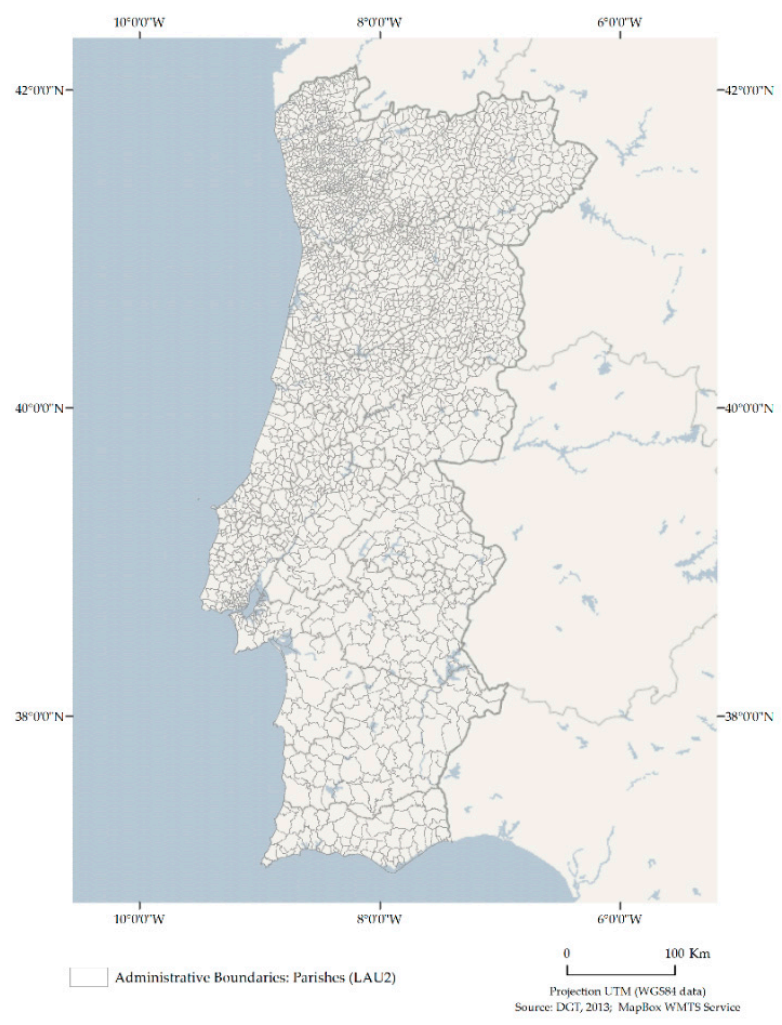

Figure 3. Mainland Portuguese territory and parish administrative boundaries in 2013. 
COS is a digital vector map product, available since 1990, where, through hierarchical nomenclature and using a minimum unit area of 1 ha, the land cover/land use is characterised diachronically in Mainland Portugal (CORINE Land Cover is a similar document [48]). The "Artificialized Territories" category is part of this nomenclature, which are "Artificialized or landscaped surfaces, intended for activities related to human societies. This class includes urban fabric areas, industrial areas, commercial areas, the road and rail network, service areas, gardens or urban parks and cultural and leisure equipment" [22]. Although the intent of this map is not to delimit urban areas, the category "Artificial Territories", with certain restrictions and in combination with other criteria, could be an illustrative indicator of the territorial extent of the urban areas. For the present study, the Artificial territories class of the 2015 COS map [49], inside the urban perimeters delimited by CRUS, were considered (Figure 4A). Thus, it is spatially and temporally comparable with the other information used, namely CRUS and TIPAU (referred to 2016 and 2014, respectively). According to this classification, 3501 sq.km can be considered urban area.
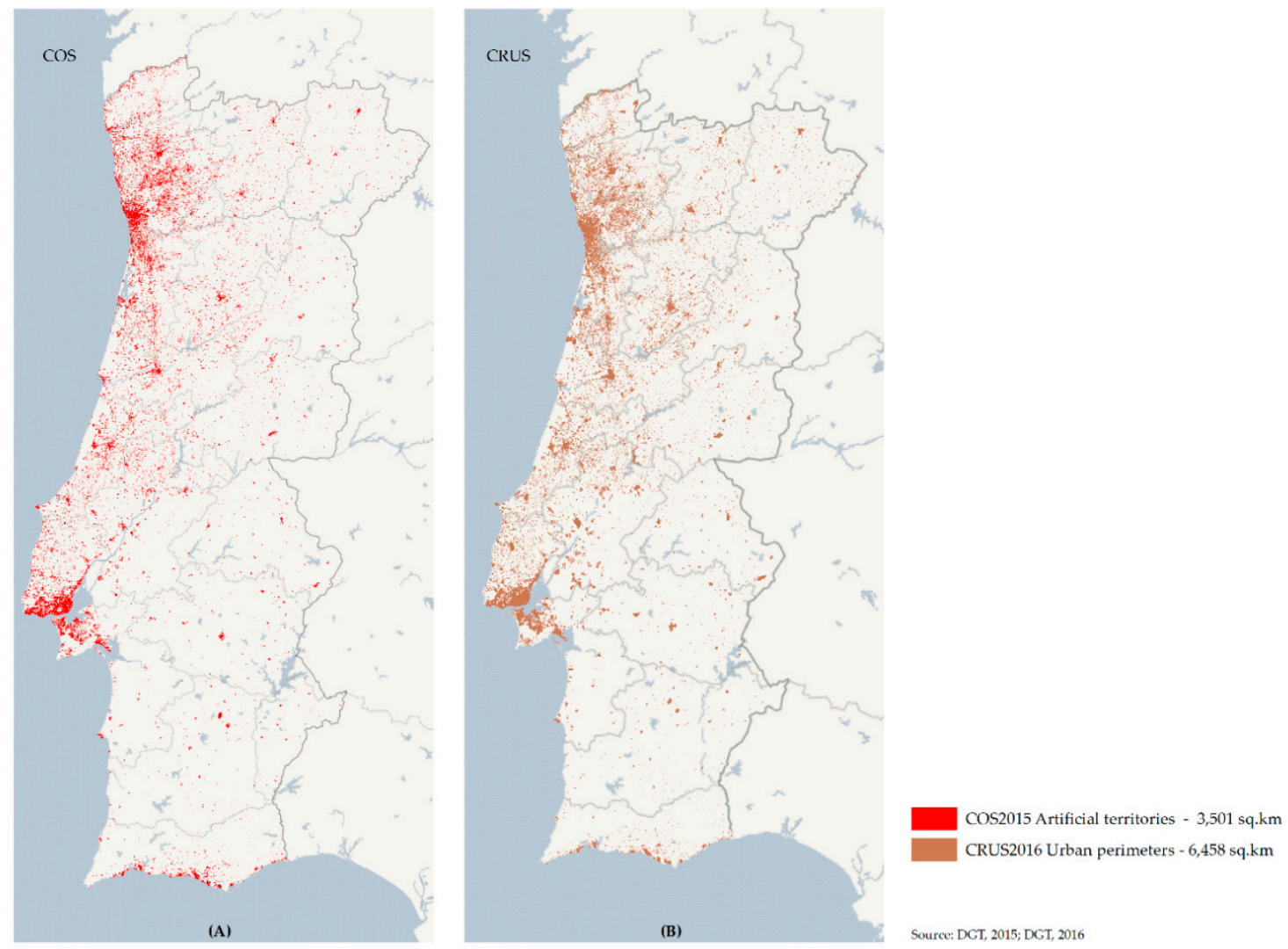

Figure 4. Artificial territories and urban perimeters according to land use and land use regime maps (A) COS 2015; (B) CRUS 2016.

CRUS (Figure 4B) gathers and harmonises information from the land use regime maps (proposed land uses for the plan horizon) of the municipal master plans of all Portuguese municipalities, in force before 2016 [50]. The information from CRUS was provided by the General Directorate for Territory Development (DGT) and does not contain data on 19 municipalities, as the revision of their Master Plans was published in the period between 2016 and 2019. The maps of these plans were prepared using several land use classes and include urban areas classified as urbanised and non-urbanised. By the time of the drawing up of these plans a legal document (Decreto Regulamentar n. ${ }^{\circ} 11 / 2009$ de 29 de Maio) "Establishes the uniform criteria for the classification and reclassification of land, the definition of dominant use, as well as the categories relating to rural and urban land, applicable to the entire national territory". It classifies urban land as that intended for urbanisation and construction and refers its classification to municipal instruments of territorial management. The municipal master 
plans, developed during the period of this legal diploma, established urban perimeters based on these criteria and, consequently, included within these perimeters the expansion areas (areas to be urbanised) defined by each municipality which are not always clear and objective [51]. According to this classification, 6458 sq.km were considered urban area for planning purposes. This significant difference between the urban area defined by COS and by CRUS reveals the prominence that urban expansion areas assume in the classification of the territory.

TIPAU is a threefold classification concerning the degree of urbanisation of the Portuguese territory, established by Statistics Portugal, at the administrative level of the parish (LAU2): "Predominantly urban areas" (APU), "Medium urban areas" (AMU) and "Predominantly rural areas" (APR). In order to carry out this classification of the parishes in mainland Portugal, Statistics Portugal relied on the figures and cartography of the 2011 census, administrative information concerning the presence/absence of the municipal headquarters, and on information from CRUS. In the absence of information from CRUS, COS was used. The criteria for labelling a parish as APU, AMU or APR has therefore combined several approaches, namely morphological criteria (population density thresholds and whether or not the parish contains a locality [37] where the municipal headquarters is located) and planning criteria. The urban localities considered are those with a population of 5000 or more inhabitants. The detailed criteria for TIPAU classification can be assessed in Statistics Portugal webpage [39].

The administrative reorganisation (amalgamation/mergers [52]) of the Portuguese territory carried out by the Government in 2012, and the consequent administrative reorganisation of the territories of the parishes, resulted in a reduction of 1168 parishes from the total of 4050 existing before this process. Given this, Statistics Portugal needed to adapt TIPAU, which had been defined in 2009, to the new administrative map of the parishes of Mainland Portugal, resulting in TIPAU 2014. To this study, the "Predominantly urban areas" (APU) were considered as representative of the urban dimension (Figure 5A), and classifies as urban area 16,458 sq.km of the territory.
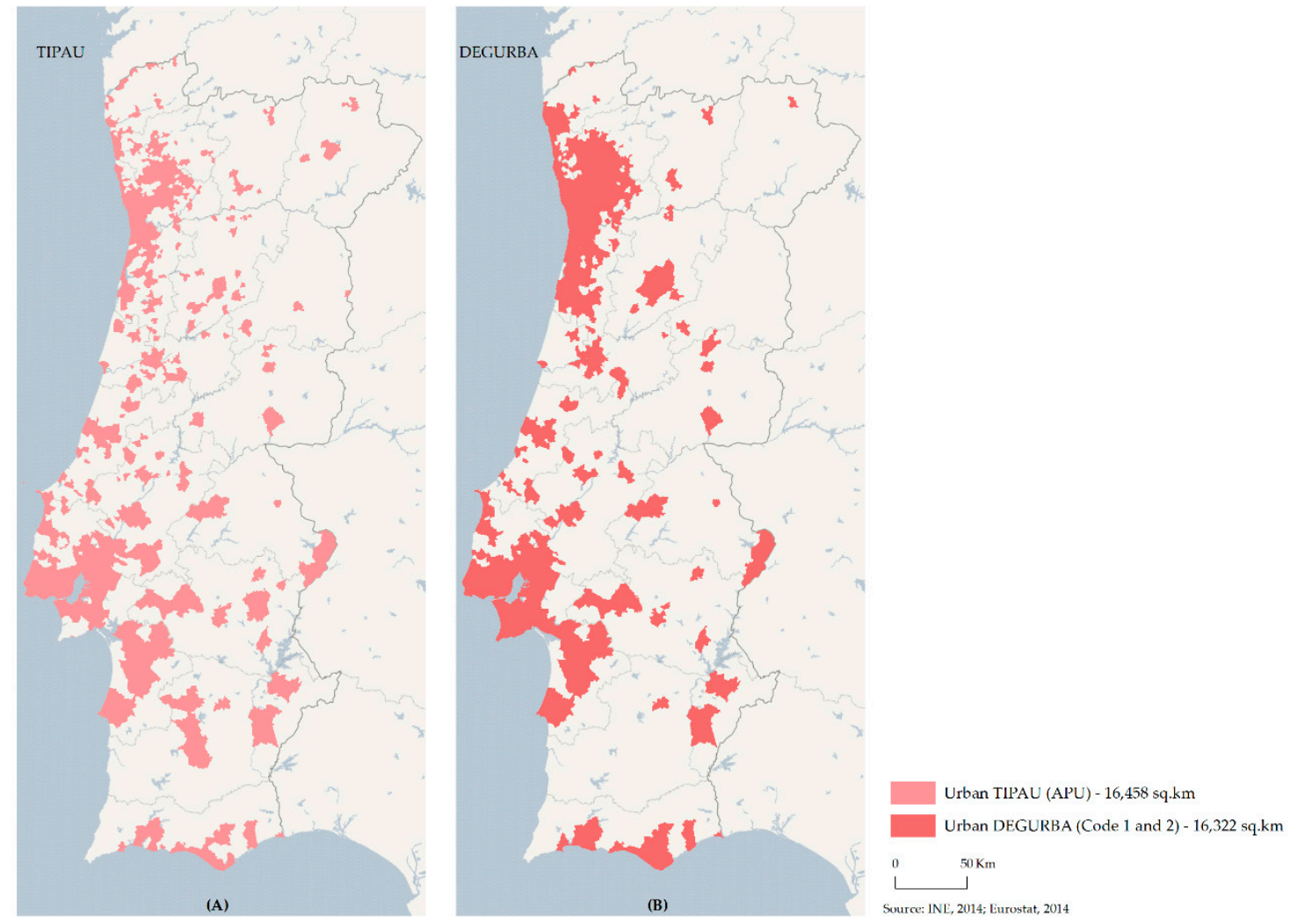

Figure 5. Urban areas according to administrative delimitations LAU2 (parishes) (A) TIPAU 2014 (APU); (B) DEGURBA 2014 (Code 1 and Code 2). 
Regarding DEGURBA 2014 (Figure 5B), urban areas refer "to an aggregate composed of information covering cities as well as towns and suburbs (in other words, densely populated areas and intermediate density areas)" [22] (p. 38), and the methodology used for their delimitation "combines geographical contiguity and population density, measured by minimum population thresholds applied to $1 \mathrm{sq} . \mathrm{km}$ population grid cells; each LAU belongs to one of the three classes". (ibid.). According to this classification, $16,322 \mathrm{sq} . \mathrm{km}$ are considered as being urban area. Comparing to TIPAU differences in area are not very significant; however, the geographical distribution is considerably different, showing a distinct map of "the urban".

As specified before, urban localities are territorial delimitations, defined by Statistics Portugal, consisting in a population cluster with 5000 or more inhabitants. Figure $6 \mathrm{~A}$ shows the territorial expression of these areas.

The 1 sq.km population grid is defined by EUROSTAT, within the GEOSTAT project, as “ . . . a lattice composed of 1 sq.km grid cells overlaying a particular territory, for which information is collected relating to the number of inhabitants. (... ) The grid is stable over time, not dependent on changes in administrative boundaries and may be used for spatial aggregations to various territories of interest" [22] (p. 7). Figure 6B shows the grid cells that are considered urban using the threshold of 300 inhabitants per sq.km, according to EUROSTAT.
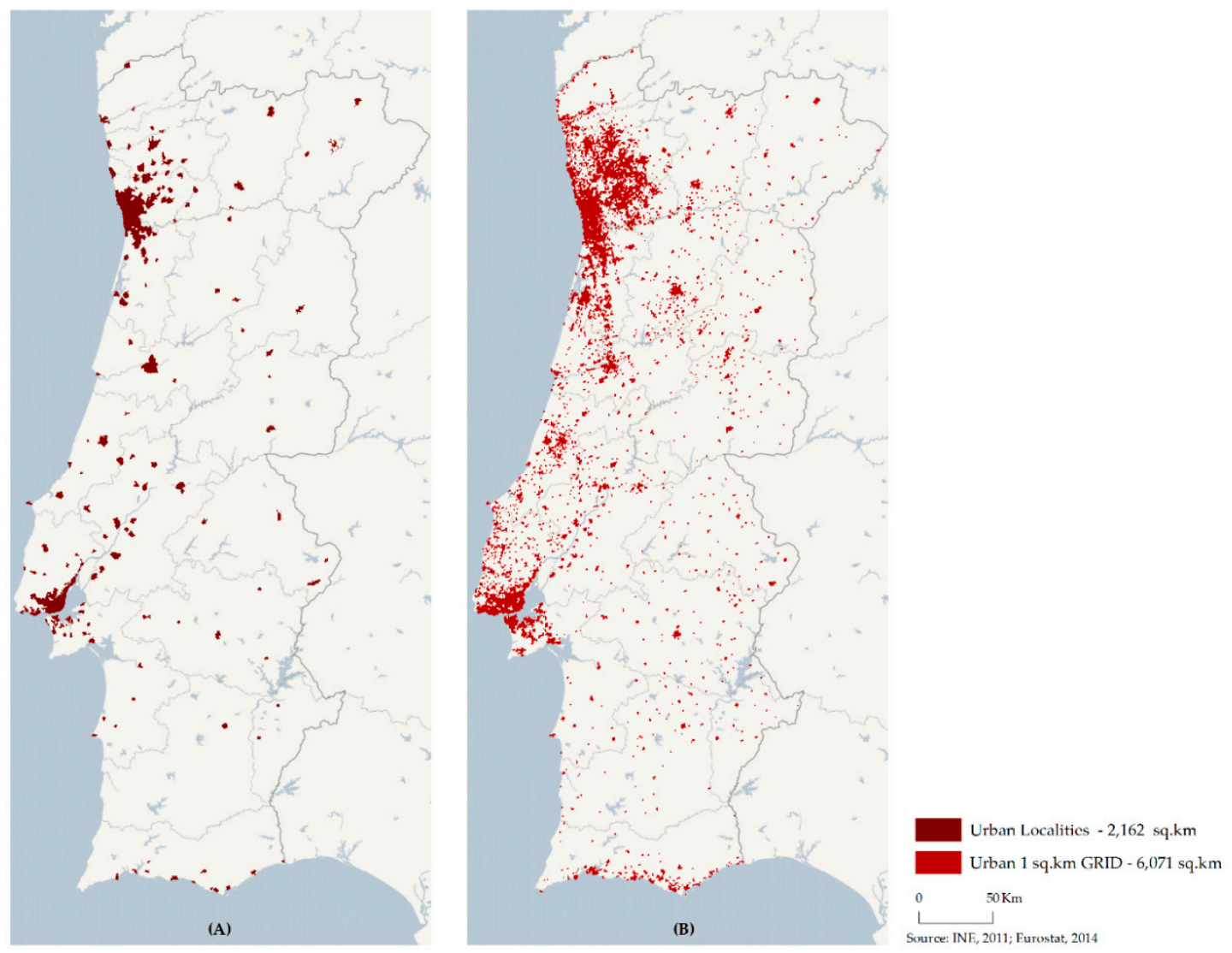

Figure 6. Urban areas according to Statistics Portugal 2011 urban localities and the GEOSTAT 2011 1 sq.km grid (A) Localities (>=5000 inhabitants); (B) 1 sq.km grid (Population density $>300$ inhabitants per sq.km).

As mentioned before, COS, CRUS, DEGURBA, and TIPAU were the classifications used in this study to discuss the relevance and suitability of the urban typologies used by official institutions. There are semantical differences between the planning approach (COS and CRUS) and the statistical approach (DEGURBA and TIPAU), and therefore the comparisons are made among each group. 
Although some changes could have occurred concerning the recent urban occupation of the territory, the data used are of a comparable period of time and are in force for statistical and planning purposes.

\section{Results}

The materials described above were analysed and combined with other indicators in order to provide a framework for the discussion of the urban dimension issue for policy making and respective planning actions, considering territorial cohesion.

The analyses were carried out looking first at the classification of the urban in morphological terms, with COS and CRUS being the main sources of information, and later for the classifications based on the administrative status of the parishes, as defined by Statistics Portugal and Eurostat (TIPAU and DEGURBA).

\subsection{Concerning the Morphological Classification of the Urban}

The artificial territories class for the COS map, within the urban perimeters defined by the master plans (CRUS), occupy 3501 sq.km, corresponding to 3.9\% of the Mainland Portuguese territory (Figure 4A). These artificial territories, even though only those within the urban perimeters were considered, do not necessarily show the urban character of a human settlement per se. The physical or architectural objects of small rural villages are, according to the COS classification, artificialized surfaces, but lack an extent, or a number of inhabitants, to have that character. Even in terms of planning issues, rural settlements are classified as rural land (Decree Law No. 15/2015).

As the delimitation of this land use class is derived mainly from aerial photo interpretation and therefore does not take in to account any administrative or statistical units from census surveys, the determination of the number of inhabitants residing in these areas cannot be precise. However, in considering the statistical subsections that have their centroid within these artificial territories, to look at the resident population, 6,441,202 inhabitants lived within these areas, in 2011. This means that $64.1 \%$ of the Mainland Portuguese population lived in artificialized territories with an urban perimeter defined by the Master plan, which does not necessarily mean urban population. If only the set of these territories that falls within localities with more than 5000 inhabitants are considered, then just $1.4 \%$ of the Mainland Portuguese territory would be urban, i.e., $47 \%$ of the total population.

Urban perimeters defined by the master plans and gathered in the 2016 CRUS map, along with other land use regime classes, demarcate areas that are urbanised or for urban development. Despite certain omissions and disparities identified by General Directorate for Territory Development, $6458 \mathrm{sq} . \mathrm{km}$ were delimited throughout the Mainland Portuguese territory and 7,887,055 inhabitants $(78 \%$ of the total population) lived within these areas. Like COS, these urban perimeters do not necessarily mean delimitations of urban areas, but rather human settlements of different sizes and hierarchical importance in the urban panorama of the country, marked off for planning purposes. Moreover, expansion areas are considered here and despite the guidelines of the National Programme for Spatial Planning Policies, in order to contain areas intended for urbanisation, these areas were often oversized in view of the population decrease verified [53], and in other situations corresponded to mere expectancies for further urbanisation developments, often associated with second residencies and tourist activity.

Following the same methodology used for COS, considering only the set of these territories which are within localities with more than 5000 inhabitants, the urban area is then $1961 \mathrm{sq} . \mathrm{km}(2.2 \%)$ and the population 5,370,705 (53.4\%).

\subsection{Concerning Administrative Classification of the Urban}

Comparing TIPAU and DEGURBA classifications of 'the urban', 357 parishes, out of the 2882 Portuguese mainland parishes, were classified differently (Figure 7). It is noteworthy that 131 parishes have a diametrically opposed classification, i.e., classified as urban by one institution and rural by the other: 98 parishes were classified as rural (Code 3) by DEGURBA while TIPAU considered them urban 
(APU); on the other hand, there were 33 parishes that DEGURBA classified as urban (Code 1 and 2) and TIPAU as rural (APR).

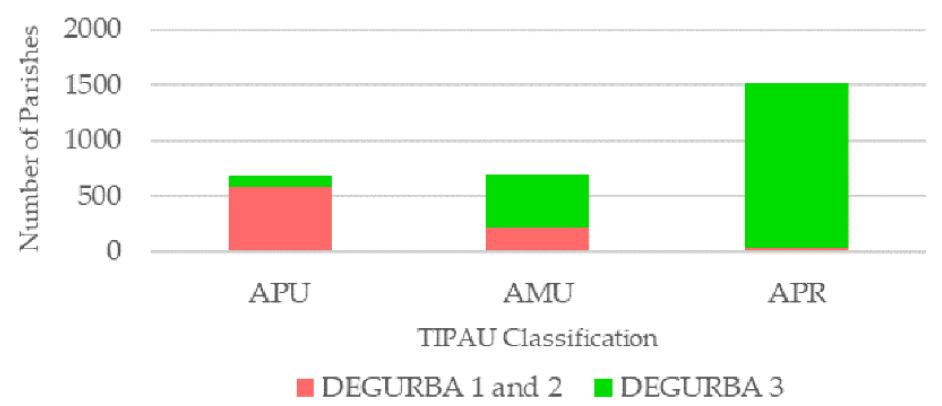

Figure 7. Number of parishes with different classification considering TIPAU 2014 and DEGURBA 2014.

Figure 8 shows the geographical distribution of this discrepancies. Where parishes are classified as urban by TIPAU (APU), DEGURBA classifies them as rural (Code 3). In contrast, where parishes are classified as urban by DEGURBA (Code 1 and 2), TIPAU classifies them as rural (APR). Although there is no well-defined pattern of distribution of discrepancies, it can be seen that parishes with a larger area, especially in the southern half of the country, tend to be classified as urban by TIPAU. Regardless of the low population densities and the tendency of negative growth that most of these parishes have shown in the last decade, the criterion of the existence of the headquarters of the municipal council was decisive in classifying them as urban.

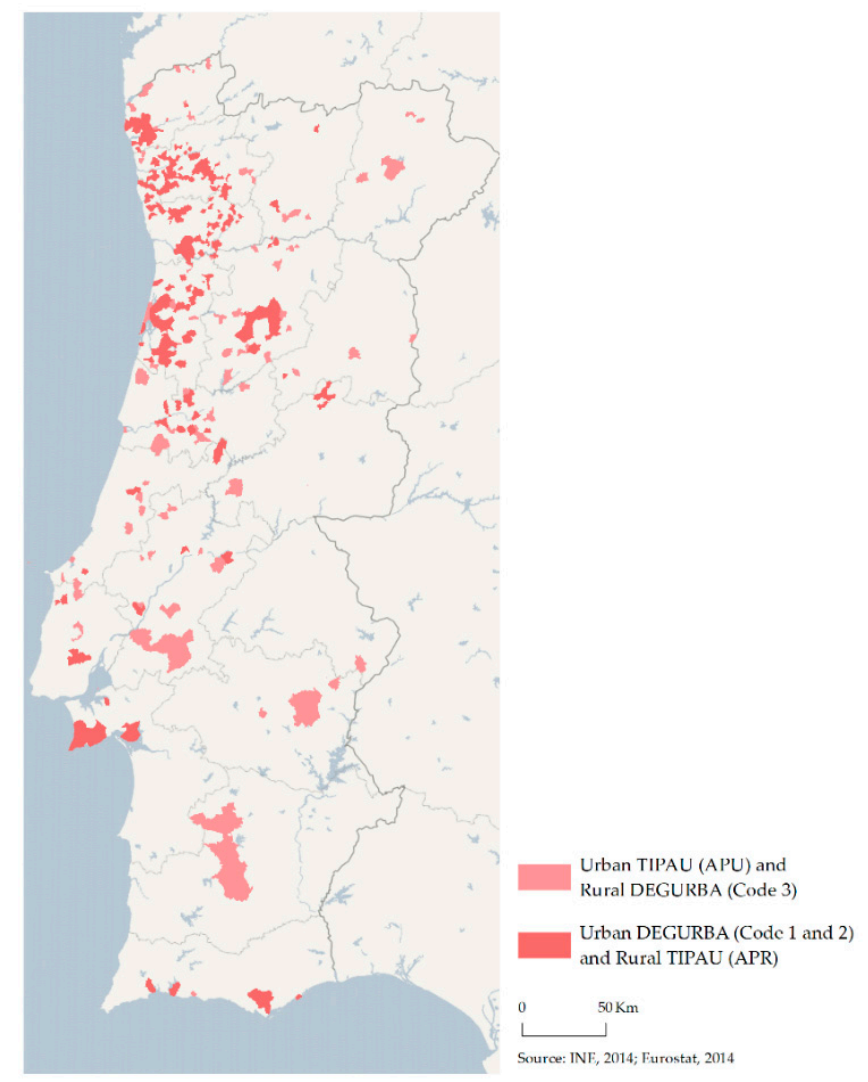

Figure 8. Parishes with different urban classification comparing TIPAU 2014 and DEGURBA 2014.

Several examples could be given to show the mismatching of one of the classifications assigned, taking into account the demographic and territorial reality. The parishes of Vale da Porca and Santa Barbara de Nexe are two of these examples that are illustrated here. Neither has the municipal 
headquarters within their territories (TIPAU criterion) and both also have less than 5000 inhabitants (DEGURBA criterion). Vale da Porca is located in the northern interior of the country, in the municipality of Macedo de Cavaleiros. TIPAU classified it as predominantly urban (APU) and DEGURBA as rural (Code 3). Between 2001 and 2011, this parish lost 18.1\% of its population, recording, in the 2011 census, 286 residents. Figure 9A shows that land use is mostly agricultural and forestry. In fact, only $2.8 \%$ of the parish area consists of artificial territories.

On the other hand, Santa Bárbara de Nexe is classified as rural (APR) by TIPAU and urban (Code 1) by DEGURBA. It is situated in the southern part of the territory, in the Algarve region and, when considering the land use (Figure $9 \mathrm{~B}$ ), $8.2 \%$ of the area corresponds to artificial territories, associated with dispersed settlements. It also lost population between 2001 and $2011(-0.1 \%)$, registering 4116 inhabitants in 2011.

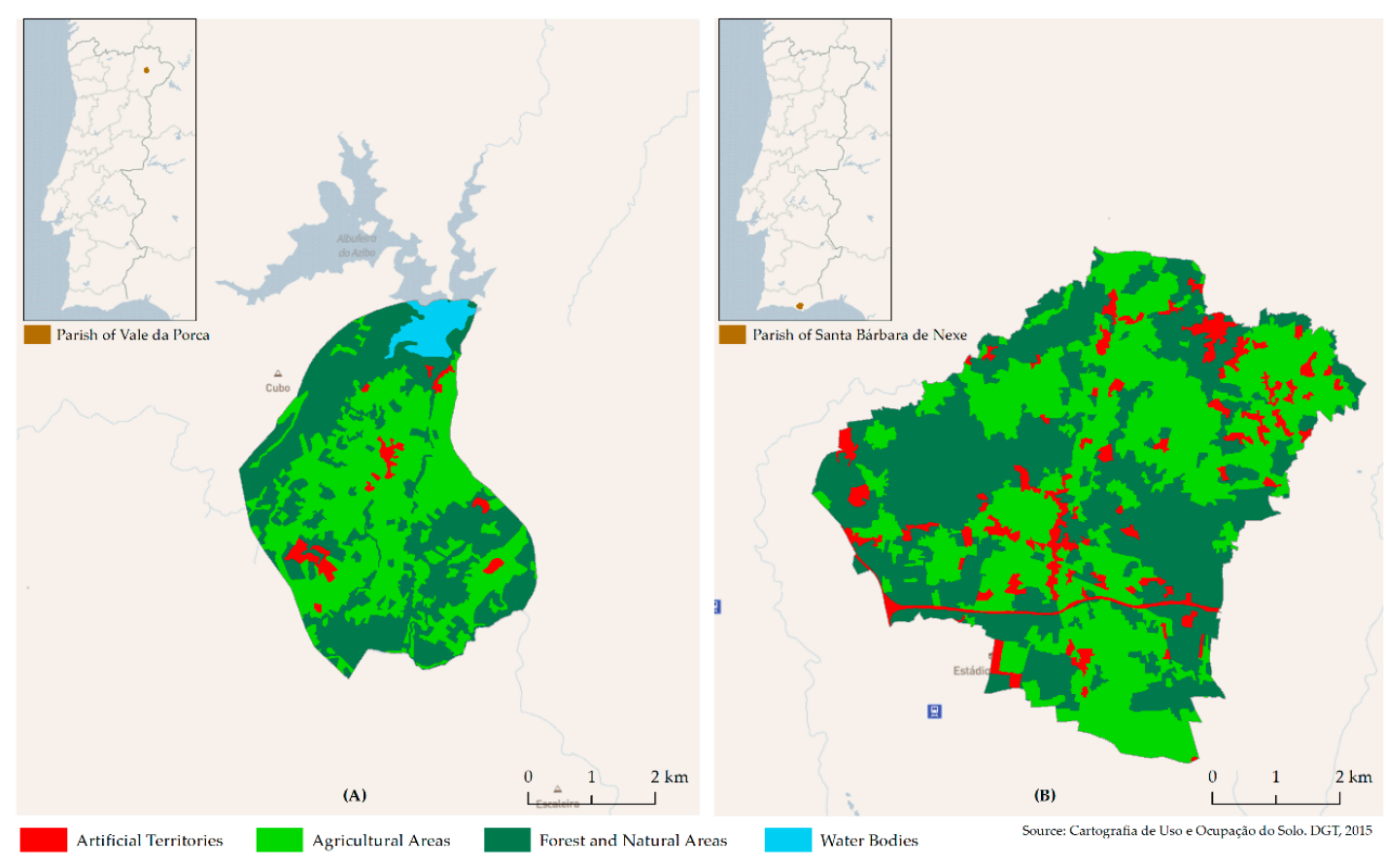

Figure 9. Land use in 2015 (A) Vale da Porca (TIPAU = APU and DEGURBA = 3); (B) Santa Barbara de Nexe $($ TIPAU $=$ APR and DEGURBA $=1)$.

Other examples having a DEGURBA classification as urban (Code 1) with a differing classification by TIPAU (APR) are the 13 distant parishes of the municipality of Viseu (Figure 10). 


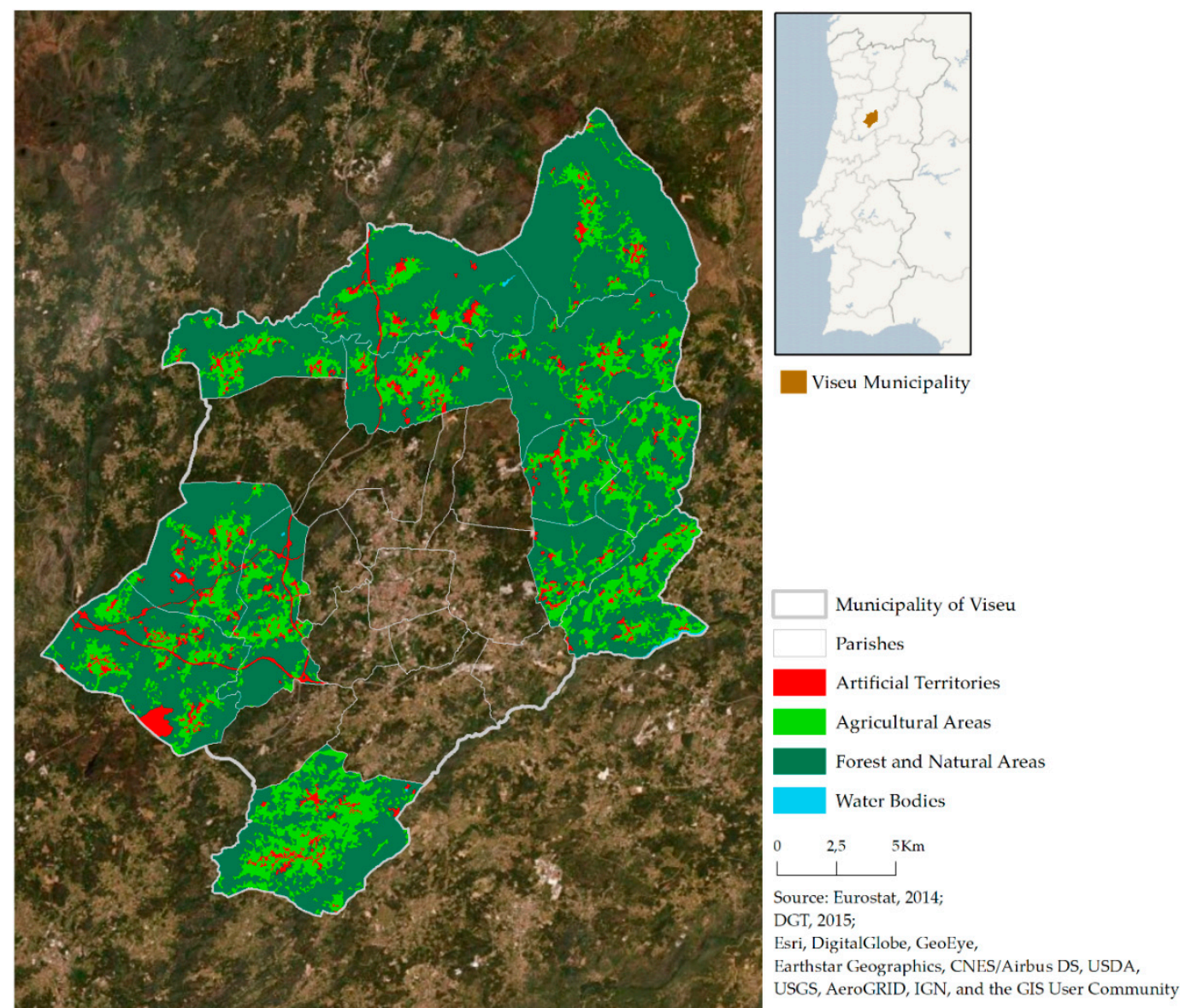

Figure 10. Parishes with a different classification between DEGURBA and TIPAU (Code 1 and APR, respectively), and land use in 2015.

As previously stated, Portugal underwent an administrative reorganisation of its territory in 2012 , leading to a considerable reduction in the number of parishes through a process of aggregation. Following the application of the TIPAU classification to the new administrative map of the parishes, the territory of Mainland Portugal went from 996 parishes classified as urban (APU), out of a total of 4050 parishes (before administrative reorganisation), to 678 parishes classified as APU, out of a total of 2882 parishes (after administrative reorganisation). In relative terms, this maintained practically the same representation of urban parishes ( $24.6 \%$ and $23.5 \%$, respectively). However, in terms of territorial size, there is now $17 \%$ more area classified as urban (APU), which means that the process of aggregating parishes along with the underlying criteria, forced a reclassification of a territorial reality which, in ssence, remains identical. At the same time, the methodology used by Statistics Portugal, although setting out morphological and spatial planning criteria, was transposed to an administrative unit resulting from the aggregation of geographical realities that can be very heterogeneous (concerning density, land use, etc.), and that the mere joining of parts may result in an administrative area classified in a way that is not representative of its somewhat urban character.

The consideration of an administrative criterion (existence of the municipal headquarters) for the classification of the parish as urban is in many cases determinant and, consequently, a factor distorting territorial reality when it comes to the urban issue. The administrative reorganisation process brought together significantly rural parishes with others which included the village or the main city of the municipality, creating new spatially vast and heterogeneous parishes.

The case of the parish of Meixedo (Figure 11A), which joined the parishes of the city of Bragança (Sé and Santa Maria), to become part of a parish considered urban, is paradigmatic of the aforementioned distortion. At a distance of more than $10 \mathrm{~km}$ from the city of Bragança, having lost $13.3 \%$ of its population 
between 2001 and 2011, and having only 1.5\% of its area artificialized ( $0.5 \%$ of the new parish), the territory of Meixedo is currently classified as urban both by TIPAU (APU) and by DEGURBA (Code 2).
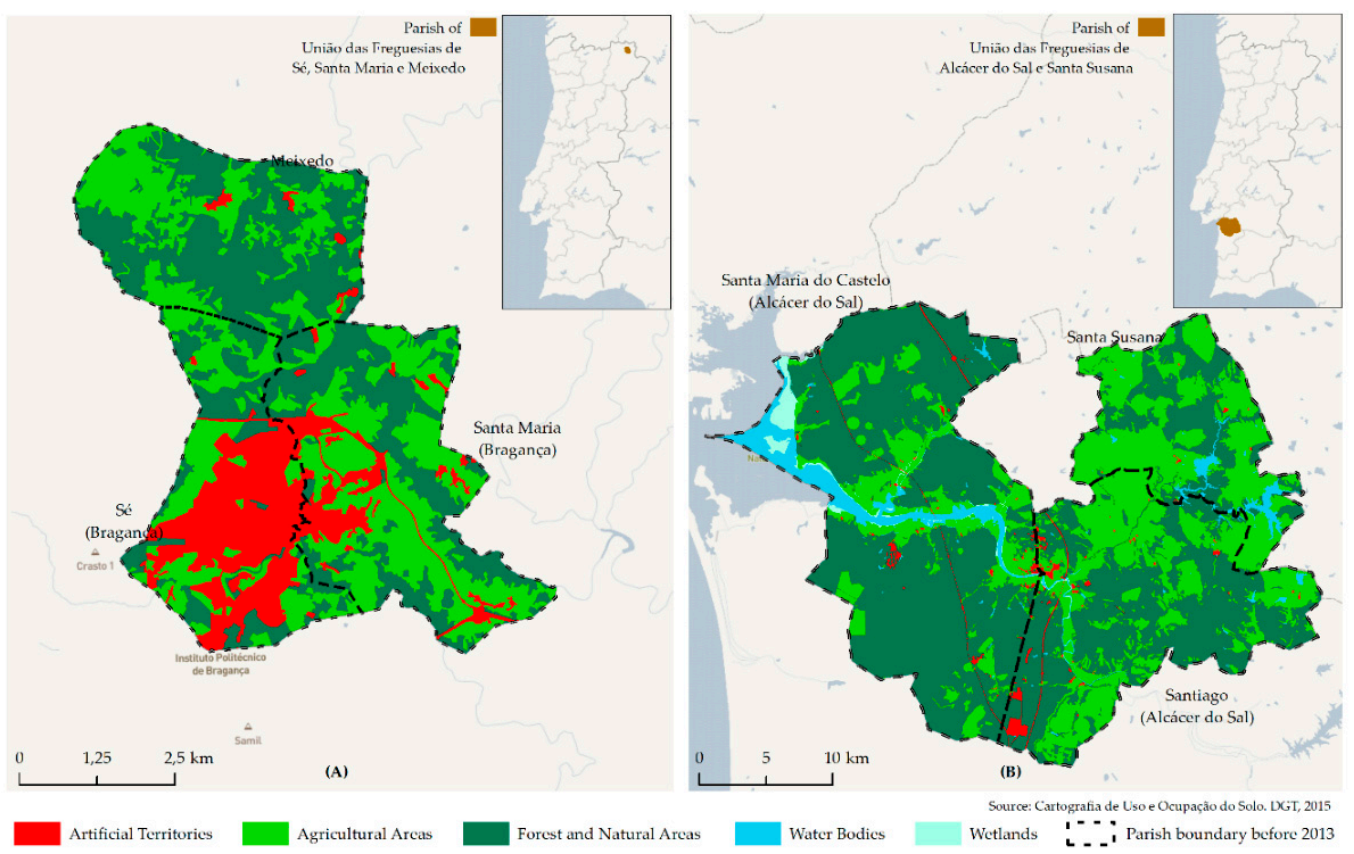

Figure 11. Land use in 2015 (A) União das Freguesias de Sé, Santa Maria e Meixedo; (B) União das Freguesias de Alcácer do Sal (Santa Maria do Castelo e Santiago) e Santa Susana.

Most of the area (80\%) of the former parish of Meixedo consists of Montesinho Natural Park (Figure 12), a protected area characterised by its immense biodiversity and small community villages which still preserve the memory of rural life.

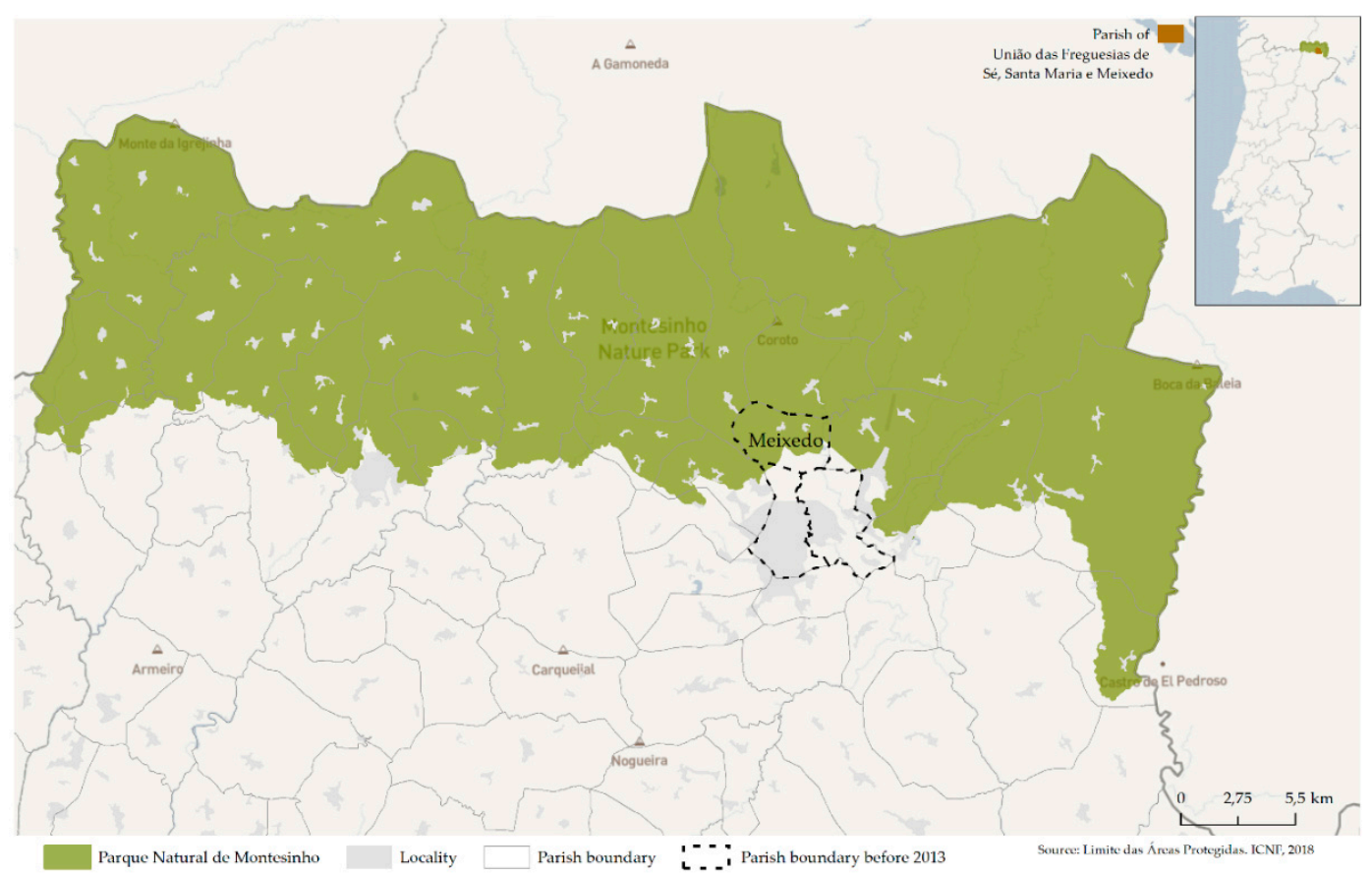

Figure 12. Parque Natural de Montesinho and the parish of União das Freguesias de Sé, Santa Maria e Meixedo. 
Another example of the distortion introduced by the administrative reorganisation regarding the classification of parishes is Alcácer do Sal. The new parish (resulting from the aggregation of Santa Maria do Castelo, Santiago, and Santa Susana) is the most extensive Portuguese parish and is classified as urban (APU) by TIPAU and also by DEGURBA (Code 2). Although it had 8831 inhabitants in 2011 (above the DEGURBA threshold of 5000 inhabitants), the population density is 10.2 inhabitants per sq.km. Between 2001 and 2011 the decrease in its population was significant $(6.1 \%$ in total, but $-29.5 \%$ in Santa Susana, which is now classified as urban following the aggregation). Considering land use in Alcácer do Sal, only $1.3 \%$ of this vast area is artificialized (Figure 11B).

Overlaying the urban parishes classified as urban either by TIPAU and by DEGURBA with the population grid cells classified as containing more than 300 inhabitants per sq.km grid, the incongruities persist and reinforce the findings stated above (Figure 13).

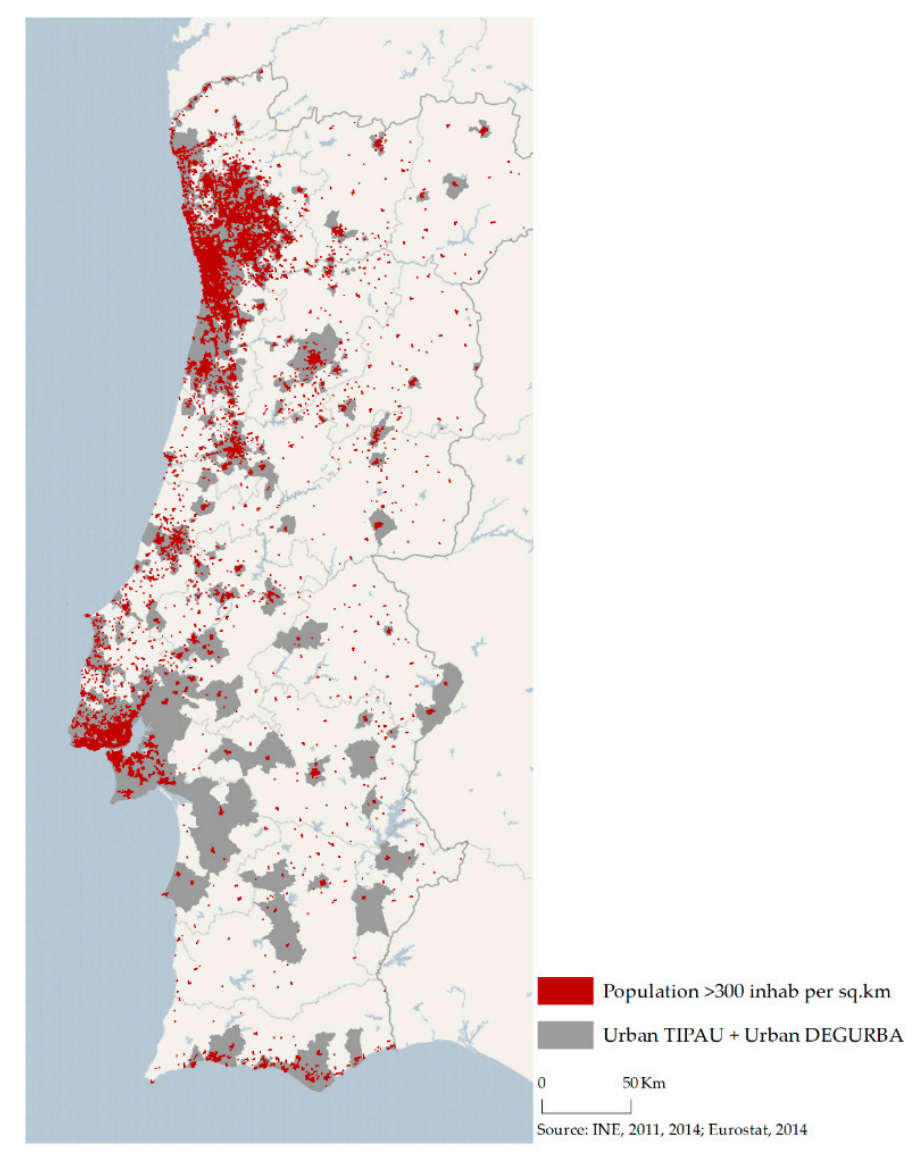

Figure 13. 1 sq.km population density in the GEOSTAT 2011 Grid, and urban areas according to TIPAU (APU) and DEGURBA (Code 1 and 2).

Considering this 1 sq.km grid, only $6.7 \%$ of the territory has a population density greater than 300 inhabitants per sq.km, but $15.1 \%$ is specified as urban by at least one of the two classification typologies. Regardless of the geographic reality, in respect to the distribution of the population across the territory, the two classifications, based on administrative boundaries, label parishes, mainly those of larger area, in an artificial way. Table 1 shows the number of parishes in terms of DEGURBA classification and population density thresholds. 
Table 1. Number of parishes by DEGURBA classification and population density.

\begin{tabular}{ccccc}
\hline \multirow{2}{*}{ DEGURBA Code } & \multicolumn{3}{c}{ Population Density Threshold ${ }^{\mathbf{1}}$} & \multirow{2}{*}{ Total } \\
\cline { 2 - 4 } & $\mathbf{1} \mathbf{1 5 0 0}$ & $\mathbf{3 0 0 - 1 5 0 0}$ & $<\mathbf{3 0 0}$ & \\
\hline 1 & 110 & 118 & 91 & 319 \\
2 & 19 & 307 & 180 & 506 \\
3 & 1 & 25 & 2031 & 2057 \\
\hline Total & 130 & 450 & 2302 & 2882 \\
\hline \multicolumn{5}{c}{ I Inhabitants per sq.km. }
\end{tabular}

The distribution of parishes according to their population does not follow the established DEGURBA density thresholds. There is a total of 319 parishes labelled Code 1 by DEGURBA. However, 91 show density figures below 300 inhabitants per sq.km, and 118 show density figures ranging between 300 and 1500 inhabitants per sq.km. Only 110 parishes, out of 319 (slightly more than a third) seem to match this DEGURBA criterion and be classified as Code 1. As for Code 2, only 307 out of 506 parishes show population density values according to the established criterion. For Code 3 , the deviation is much less pronounced, i.e., 2031 out of 2057 parishes match the criterion. Nevertheless, in this group there is a parish, with more than 1500 inhabitants per sq.km, completely misplaced within Code 3. This parish, Borba (in the municipality of Borba, NUTS III Alentejo Central, NUTS II Alentejo), has $98 \%$ of its land use as "artificial territories", and a population of 758 inhabitants in an area of 0.2 sq.km (density 3720.2 inhabitants per sq.km).

Matching the two DEGURBA criteria (population density and number of inhabitants thresholds) the results are not always consistent: 76 parishes out of the 319 classified as Code 1 (23.8\%) simultaneously show population densities below 300 inhabitants sq.km and inhabitants below 5000 (Table 2).

Table 2. Number of parishes by DEGURBA classification, population density, and number of inhabitants.

\begin{tabular}{cccccc}
\hline \multirow{2}{*}{$\begin{array}{c}\text { DEGURBA } \\
\text { Code }\end{array}$} & $\begin{array}{c}\text { Population } \\
\text { Density }\end{array}$ & \multicolumn{3}{c}{ Inhabitants Threshold } & \multirow{2}{*}{ Total } \\
\cline { 3 - 5 } & Threshold $\mathbf{1}$ & $\mathbf{< 5 0 0 0}$ & $\mathbf{5 0 0 0 - 5 0 , 0 0 0}$ & $\mathbf{2 5 0 , 0 0 0}$ & \\
\hline \multirow{2}{*}{1} & $<300$ & 76 & 15 & 0 & 91 \\
& $300-1500$ & 70 & 48 & 0 & 118 \\
& $>1500$ & 0 & 100 & 10 & 110 \\
\hline \multirow{2}{*}{2} & $<300$ & 120 & 60 & 0 & 180 \\
& $300-1500$ & 190 & 117 & 0 & 307 \\
& $>1500$ & 3 & 16 & 10 & 19 \\
\hline 3 & $<300$ & 1994 & 37 & 0 & 2031 \\
& $300-1500$ & 20 & 5 & 0 & 25 \\
& $>1500$ & 1 & 0 & 0 & 1 \\
\hline & Total & 2474 & 398 & 10 & 2882 \\
\hline
\end{tabular}

Taking a concrete example within this set of 76 parishes, the parish of Amonde (in the municipality of Viana do Castelo, NUTS III Alto Minho, NUTS II Norte), has 5\% of its land use as "artificial territories", a population of 293 inhabitants in 2011 (14.8\% less than in 2001) and a population density of 46.9 inhabitants per sq.km (with an area of 6.25 sq.km), is labelled as Code 1.

Looking from the perspective of the population threshold, there is a total of 146 parishes (Code 1) and another total of 313 parishes (Code 2) that do not have the minimum of 5000 inhabitants. Those two groups of parishes account for $18.6 \%$ of parishes with less than 5000 inhabitants. According to the DEGURBA criteria, the 163 parishes labelled as Code 1 that range from 5000 to 50,000 inhabitants should not have that classification. Given this, only 2121 parishes (grey background), corresponding to $73.6 \%$ of the total, follow the DEGURBA criteria. 
In relation to the TIPAU classification, the criteria established was built upon a wider set of conditions and requisites involving interdependencies and combines a mix of quantitative (number of inhabitants), morphological (the parishes containing certain localities (totally or partially)) and administrative (the parish contains the headquarters of the municipality) criteria.

Although it is almost impossible to analyse the matching of TIPAU classification to quantitative criteria, as it was above for the DEGURBA classification (which relies on objective and measurable criteria), it is however possible to analyse the results for TIPAU according to the thresholds defined by DEGURBA.

As shown in Table 3, 174 out of the total 678 labelled as APU (25.7\%) present population density figures below 300 inhabitants per sq.km.

Table 3. Number of parishes by TIPAU class and population density threshold.

\begin{tabular}{|c|c|c|c|c|}
\hline \multirow{2}{*}{ TIPAU } & \multicolumn{3}{|c|}{ Population Density Threshold ${ }^{1}$} & \multirow{2}{*}{ Total } \\
\hline & $>1500^{1}$ & $300-1500^{1}$ & $<300^{1}$ & \\
\hline APU & 130 & 374 & 174 & 678 \\
\hline AMU & 0 & 76 & 612 & 688 \\
\hline APR & 0 & 0 & 1516 & 1516 \\
\hline Total & 130 & 450 & 2302 & 2882 \\
\hline
\end{tabular}

Taking a concrete example, the parish of Vale Benfeito (in the municipality of Macedo de Cavaleiros, NUTS III Terras de Trás-os-Montes, NUTS II Norte), located more than $10 \mathrm{~km}$ away from the headquarters of the municipality, with 181 inhabitants in 2011 (21.6\% less than in 2001), an area of 15.14 sq.km (12 inhabitants per sq.km), was labelled as APU (Figure 14A). The criterion for the inclusion of its small village within the perimeter of the location of the head of the municipality (despite its population representing only $2.1 \%$ ) prevailed.

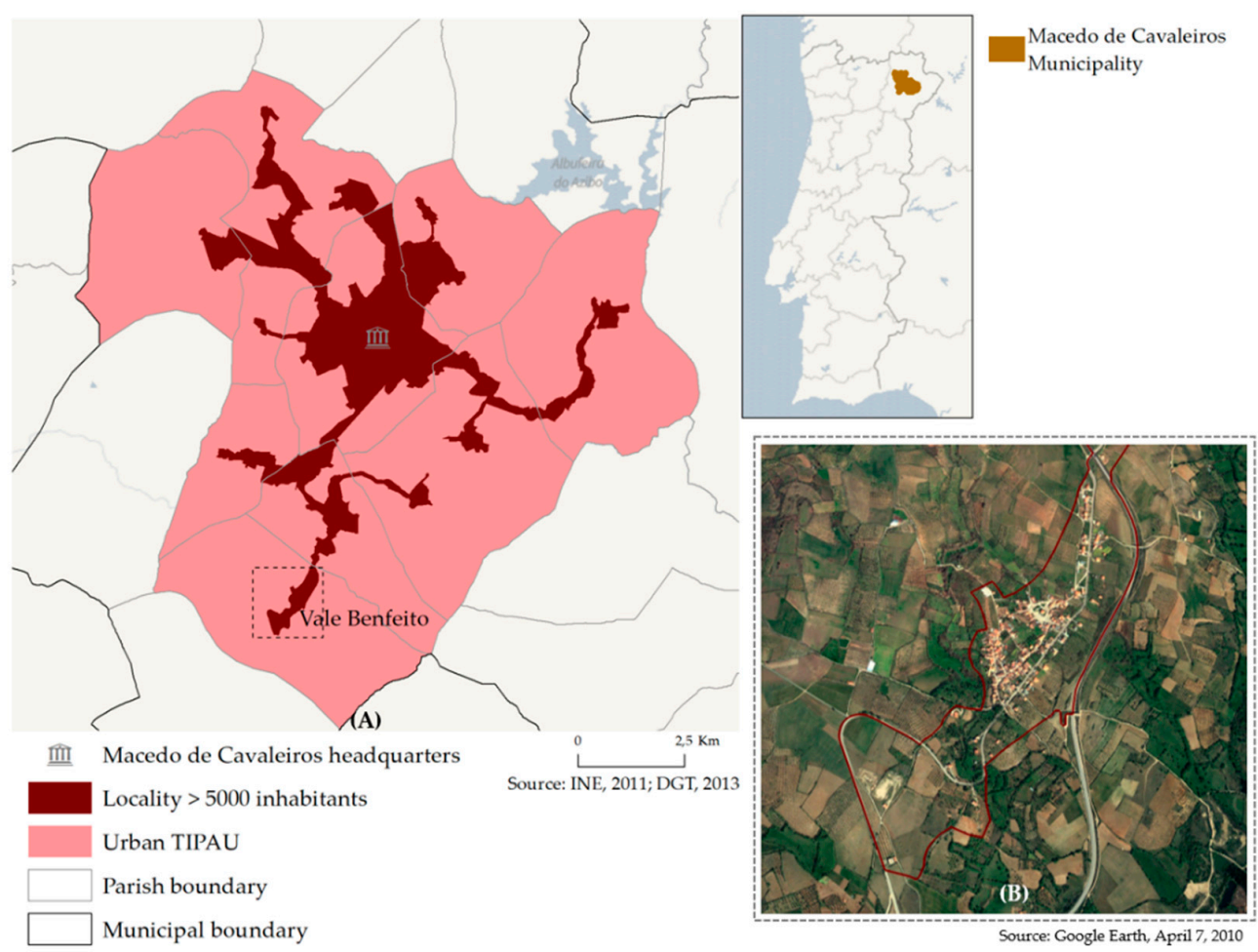

Figure 14. (A) Macedo de Cavaleiros locality and the parishes of the municipality of Macedo de Cavaleiros classified as APU (TIPAU); (B) Aerial image of Vale Benfeito village. 
The land use data (COS) shows a minimum level of urbanisation, with only $0.7 \%$ of artificialized areas. DEGURBA attributed this parish with Code 3, the opposite extreme. The introduction of the locality and administrative criteria is also responsible for other similar situations not only in this municipality (since the locality containing the headquarters of the municipality is over 5000 inhabitants and spreads over eight parishes), but also in other areas of Continental Portugal.

\subsection{Demographic and Socio-Economic Indicators of the Urban}

Considering the results of the research presented above (Section 3.2), 10 parishes were analysed, consisting of a subset of the 98 where DEGURBA and TIPAU classifications differ (all of them being Code 3 for DEGURBA and, at the opposite extreme, APU for TIPAU). These 10 parishes also have in common the fact that they were labelled as APU (TIPAU) because all of them partially or totally contain the locality where the headquarters of the municipality is located (the administrative criterion for TIPAU), and all of them have more than 5000 inhabitants. These 10 parishes do not refer to a specific Portuguese mainland area or region; instead, they cover a wide spectre of territorial locations, in the north, centre and south, being both coastal and inland territories.

As shown in Table 4, the localities with the municipal headquarters contained within (the reason why these parishes were labelled as APU) occupy a very small part of the parishes' territory-in some of the cases not even $1 \%$ of the whole territory (as is the case in Redondo, UF de Ferreira do Alentejo e Canhestros and UF de Castro Verde e Casével). In contrast to these are the "other territories" that can reach as far as $99.5 \%$ of the whole parish territory ("Other territories" includes all the surface of the parish excluding the area belonging to the locality where the municipal headquarters is located. This vast territory may have all types of land use, mainly agricultural, forestry, natural landscapes, water bodies, and can also contain inhabited places-usually exceedingly small villages (under 10 inhabitants)—and isolated dwellings).

Table 4. Area and Artificial territories of APU (TIPAU) and Code 3 (DEGURBA) parishes, their localities (with the municipal headquarters), and other territories.

\begin{tabular}{|c|c|c|c|c|c|c|c|c|c|c|c|}
\hline \multirow{3}{*}{ Parish } & \multirow{3}{*}{$\begin{array}{c}\text { Total Area } \\
\text { sq.km }\end{array}$} & \multirow{2}{*}{\multicolumn{2}{|c|}{ Locality }} & \multirow{2}{*}{\multicolumn{2}{|c|}{$\begin{array}{c}\text { Other } \\
\text { Territories }\end{array}$}} & \multicolumn{6}{|c|}{ Artificial Territories } \\
\hline & & & & & & \multicolumn{2}{|c|}{ Parish } & \multicolumn{2}{|c|}{ Locality } & \multicolumn{2}{|c|}{$\begin{array}{c}\text { Other } \\
\text { Territories }\end{array}$} \\
\hline & & sq.km & $\%$ & sq.km & $\%$ & sq.km & $\%$ & sq.km & $\%$ & sq.km & $\%$ \\
\hline Soure & 92.3 & 2.3 & 2.5 & 90.0 & 97.5 & 6.9 & 7.5 & 0.9 & 36.8 & 6.1 & 6.8 \\
\hline Mira & 63.1 & 3.9 & 6.2 & 59.2 & 93.8 & 6.8 & 10.8 & 1.4 & 35.4 & 5.5 & 9.2 \\
\hline $\begin{array}{l}\text { UF de Refojos de Basto, } \\
\text { Outeiro e Painzela }\end{array}$ & 29.0 & 1.5 & 5.2 & 27.5 & 94.8 & 3.5 & 11.9 & 1.0 & 67.2 & 2.4 & 8.9 \\
\hline Sertã & 81.0 & 2.5 & 3.1 & 78.4 & 96.9 & 5.0 & 6.2 & 1.1 & 44.6 & 3.9 & 4.9 \\
\hline Miranda do Corvo & 46.5 & 2.1 & 4.4 & 44.5 & 95.6 & 4.0 & 8.6 & 1.0 & 46.4 & 3.0 & 6.9 \\
\hline $\begin{array}{c}\text { UF de Bombarral e Vale } \\
\text { Covo }\end{array}$ & 29.5 & 1.9 & 6.6 & 27.6 & 93.5 & 3.6 & 12.1 & 1.2 & 62.8 & 2.4 & 8.5 \\
\hline Redondo & 307.8 & 1.4 & 0.5 & 306.4 & 99.6 & 3.1 & 1.0 & 1.0 & 70.8 & 2.1 & 0.7 \\
\hline $\begin{array}{c}\text { UF de Ferreira do } \\
\text { Alentejo e Canhestros }\end{array}$ & 295.7 & 1.5 & 0.5 & 294.2 & 99.5 & 5.8 & 2.0 & 1.2 & 83.1 & 4.5 & 1.5 \\
\hline $\begin{array}{c}\text { UF de Castro Verde e } \\
\text { Casével }\end{array}$ & 322.8 & 2.9 & 0.9 & 319.8 & 99.1 & 6.1 & 1.9 & 1.5 & 52.2 & 4.5 & 1.4 \\
\hline $\begin{array}{l}\text { UF de Aljustrel e Rio de } \\
\text { Moinhos }\end{array}$ & 228.8 & 2.6 & 1.15 & 226.2 & 98.9 & 6.1 & 2.7 & 1.8 & 66.6 & 4.3 & 1.9 \\
\hline
\end{tabular}

The figures for the artificial territories of these parishes are also extremely low. In the three parishes mentioned above, they represent just over $1 \%$ of the whole area. The artificial territory of the locality, depending whether the locality is more compact and denser in terms of building and construction, varies between $35.4 \%$ and $83.1 \%$ of the locality surface area. Nevertheless, the area of artificial territories of the "other territories" is also extremely low (between $0.7 \%$ and $9.2 \%$ ).

Table 5 shows that the proportion of the population belonging to the locality where the municipal headquarters is located varies to a large extent (in this sample, from $23.1 \%$ to $78.6 \%$ ), to the same extent as the part of the parishes' population living outside the locality varies (from $21.4 \%$ to $76.9 \%$ ). 
In these parishes the population living in small villages, sometimes not more than small clusters of rural dwellings (with less than 100 inhabitants) or a farm, or even in isolated dwellings, which may be distant from the main locality by more than several dozen kilometres, can be significantly representative, but the urban character of this population is very arguable. For example, in the parish of Soure, $23.1 \%$ of the population lives in only $2.5 \%$ of the parish territory and the rest of the population $(76.9 \%)$ lives in scattered places spread all over the parish territory ( $97.5 \%$ of the total territory), with the $27.5 \%$ being in villages under 100 inhabitants and in isolated dwellings.

Table 5. Number and percentage of inhabitants in localities with the municipal headquarters, and other territories according to their population size, belonging to APU (TIPAU) and Code 3 (DEGURBA) parishes.

\begin{tabular}{|c|c|c|c|c|c|c|c|c|c|c|}
\hline \multirow{2}{*}{ Parish } & \multirow{2}{*}{\multicolumn{2}{|c|}{ Locality }} & \multicolumn{7}{|c|}{ Other Territories } & \multirow{2}{*}{ Total } \\
\hline & & & 800-999 & $600-799$ & $400-599$ & $200-399$ & 100-199 & 0-99 & Residual & \\
\hline \multirow{2}{*}{ Soure } & No. & 1831 & & & 1365 & 1523 & 1026 & 1945 & 227 & 7917 \\
\hline & $\%$ & 23.1 & & & 17.2 & 19.2 & 13.0 & 24.6 & 2.9 & 100.0 \\
\hline \multirow{2}{*}{ Mira } & No. & 2001 & & 1542 & 849 & 2410 & 509 & 37 & 19 & 7367 \\
\hline & $\%$ & 27.2 & & 20.9 & 11.5 & 32.7 & 6.9 & 0.5 & 0.3 & 100.0 \\
\hline \multirow{2}{*}{$\begin{array}{l}\text { UF de Refojos de Basto, } \\
\text { Outeiro e Painzela }\end{array}$} & No. & 2257 & & & & 1330 & 2453 & 598 & 117 & 6755 \\
\hline & $\%$ & 33.4 & & & & 19.7 & 36.3 & 8.9 & 1.7 & 100.0 \\
\hline \multirow{2}{*}{ Sertã } & No. & 2291 & & & 442 & & 1380 & 1867 & 216 & 6196 \\
\hline & $\%$ & 37.0 & & & 7.1 & & 22.3 & 30.1 & 3.5 & 100.0 \\
\hline \multirow{2}{*}{ Miranda do Corvo } & No. & 3262 & & 724 & 821 & 1451 & 753 & 553 & 50 & 7614 \\
\hline & $\%$ & 42.8 & & 9.5 & 10.8 & 19.1 & 9.9 & 7.3 & 0.7 & 100.0 \\
\hline \multirow{2}{*}{$\begin{array}{c}\text { UF de Bombarral e Vale } \\
\text { Covo }\end{array}$} & No. & 4426 & 882 & & 427 & 270 & 376 & 332 & 108 & 6821 \\
\hline & $\%$ & 64.9 & 12.9 & & 6.3 & 4.0 & 5.5 & 4.9 & 1.6 & 100.0 \\
\hline \multirow{2}{*}{ Redondo } & No. & 3776 & & & 435 & 334 & 449 & 527 & 212 & 5733 \\
\hline & $\%$ & 65.9 & & & 7.6 & 5.8 & 7.8 & 9.2 & 3.7 & 100.0 \\
\hline UF de Ferreira do & No. & 3669 & & & 428 & & 354 & 397 & 292 & 5140 \\
\hline Alentejo e Canhestros & $\%$ & 71.4 & & & 8.3 & & 6.9 & 7.7 & 5.7 & 100.0 \\
\hline \multirow{2}{*}{$\begin{array}{c}\text { UF de Castro Verde e } \\
\text { Casével }\end{array}$} & No. & 4199 & & & & 273 & 243 & 352 & 279 & 5346 \\
\hline & $\%$ & 78.5 & & & & 5.1 & 4.5 & 6.6 & 5.2 & 100.0 \\
\hline \multirow{2}{*}{$\begin{array}{l}\text { UF de Aljustrel e Rio de } \\
\text { Moinhos }\end{array}$} & No. & 4621 & & 721 & & & 350 & 166 & 20 & 5878 \\
\hline & $\%$ & 78.6 & & 12.3 & & & 6.0 & 2.8 & 0.3 & 100.0 \\
\hline
\end{tabular}

Combining data shown in Tables 5 and 6, and regarding this same parish, it is possible to detect that almost a fourth (24.6\%) of the parish's population lives scattered in 39 localities where the population level is below 100 inhabitants. As a whole, the population density for this parish (85.8 inhabitants per sq.km) is rather below any standards for an urban classification, but the prevailing TIPAU administrative criterion classified it as APU. For DEGURBA, as stated before, this parish was labelled Code 3 (a rural area).

Table 6. Number of other territories belonging to APU (TIPAU) and Code 3 (DEGURBA) parishes, according to their population size.

\begin{tabular}{|c|c|c|c|c|c|c|c|c|}
\hline Parish & Locality & \multicolumn{6}{|c|}{ Other Territories } & Total \\
\hline Soure & 1 & & & 3 & 6 & 7 & 39 & 56 \\
\hline UF de Refojos de Basto, Outeiro e Painzela & 1 & & & & 5 & 16 & 11 & 33 \\
\hline Sertã & 1 & & & 1 & & 10 & 49 & 61 \\
\hline Redondo & 1 & & & 1 & 1 & 3 & 17 & 23 \\
\hline UF de Ferreira do Alentejo e Canhestros & 1 & & & 1 & & 2 & 10 & 14 \\
\hline UF de Castro Verde e Casével & 1 & & & & 1 & 2 & 7 & 11 \\
\hline UF de Aljustrel e Rio de Moinhos & 1 & & 1 & & & 2 & 2 & 6 \\
\hline
\end{tabular}


The data shown in Tables 7 and 8 illustrate how the indicators related to the parish populations differ when this concerns the population living in the locality or the population living in the remaining part of the parishes' territory. In all of them the Youth Index (YI) is higher in the locality than within the population residing in the remaining territory; as for the Ageing Index (AI) the situation is precisely the opposite: the numbers are always higher within the population residing in the remaining territory (over 50\% in three of them) and almost two times higher, as can be observed in the parish of UF de Castro Verde e Casével. As for the Old-Age Dependency Ratio (ODR), the pattern is almost the same as for the Ageing Index. With only one exception (Mira), the numbers are higher in the population figures of the "other territories" and, for the Ageing Index, the largest amplitude was found in the parish of UF de Castro Verde e Casével.

Table 7. Age groups (\%) and demographic indices in localities with the municipal headquarters, and other territories belonging to APU (TIPAU) and Code 3 (DEGURBA) parishes.

\begin{tabular}{|c|c|c|c|c|c|c|c|c|c|c|c|c|}
\hline \multirow{2}{*}{ Parish } & \multicolumn{3}{|c|}{ Locality } & \multicolumn{3}{|c|}{ Other Territories } & \multicolumn{3}{|c|}{ Locality } & \multicolumn{3}{|c|}{ Other Territories } \\
\hline & 0-14 & $15-64$ & $\geq 65$ & 0-14 & $15-64$ & $\geq 65$ & $\mathrm{AI}^{1}$ & $\mathbf{Y I}^{2}$ & $\mathrm{ODR}^{3}$ & $\mathrm{AI}^{1}$ & $\mathrm{YI}^{2}$ & ODR $^{3}$ \\
\hline Soure & 15.4 & 61.8 & 22.8 & 11.7 & 61.6 & 26.7 & 147.9 & 67.6 & 36.8 & 227.9 & 43.9 & 43.4 \\
\hline $\begin{array}{l}\text { UF de Refojos de Basto, } \\
\text { Outeiro e Painzela }\end{array}$ & 18.3 & 66.5 & 15.2 & 17.8 & 66.3 & 16.0 & 83.1 & 120.4 & 22.9 & 89.8 & 111.4 & 24.1 \\
\hline Sertã & 17.3 & 62.9 & 19.9 & 14.4 & 61.9 & 23.6 & 114.9 & 87.0 & 31.6 & 163.9 & 61.0 & 38.2 \\
\hline Redondo & 13.6 & 64.2 & 22.3 & 12.0 & 61.6 & 26.4 & 164.3 & 60.9 & 34.7 & 220.0 & 45.5 & 42.9 \\
\hline $\begin{array}{c}\text { UF de Ferreira do } \\
\text { Alentejo e Canhestros }\end{array}$ & 13.4 & 60.6 & 26.1 & 10.7 & 59.6 & 29.7 & 195.1 & 51.3 & 43.0 & 276.6 & 36.2 & 49.9 \\
\hline $\begin{array}{c}\text { UF de Castro Verde e } \\
\text { Casével }\end{array}$ & 14.9 & 65.9 & 19.2 & 12.5 & 57.2 & 30.3 & 128.5 & 77.8 & 29.1 & 243.4 & 41.1 & 53.0 \\
\hline
\end{tabular}

${ }^{1} \mathrm{AI}$ (Ageing Index) - “"The ratio between the young population and elderly population, usually defined as the quotient between the number of people aged between 0 and 14 years and the number of people aged 65 and over (usually expressed as 100 (10^2) people aged 65 and over)" [54]; ${ }^{2}$ YI (Youth Index)—“The ratio of the number of elderly persons of an age when they are generally economically inactive (aged 65 and over) to the number of young persons (from 0 to 14)" [54]; ${ }^{3}$ ODR (Old-age Dependency Ratio) - “The ratio of the number of elderly persons of an age when they are generally economically inactive (aged 65 and over) to the number of persons of working age (from 15 to 64$)^{\prime \prime}$ [55].

As Table 8 also illustrates, illiteracy rates are always higher amid the population residing in "others territories" than in the locality (sometimes three or almost four times higher as is the case in the parish of UF de Aljustrel e Rio de Moinhos and in the parish of UF de Castro Verde e Casével). As for the distribution of the employed population, according to CAE-Rev.3 (Portuguese classification of economic activities [56], corresponding to NACE Rev.2, the statistical classification of economic activities in the European Community [57]), with only one exception (Miranda do Corvo), the percentage of the population in the Primary Sector is always higher among the population residing in "other territories" than in the locality, sometimes considerably higher (six or seven times higher as is the case in the parish of UF de Castro Verde e Casével and in the parish of UF de Aljustrel e Rio de Moinhos). This percentage frequently reaches values such as those in the parishes of UF de Ferreira do Alentejo e Canhestros, Redondo, and UF de Castro Verde e Casével (38.3\%, 34\% and 25.2\%, respectively).

Not included in this set of 10 parishes, where the TIPAU and DEGURBA classifications are discordant (APU and Code 3, respectively), there are other situations where both classifications labelled the same parishes differently as they do not extensively match DEGURBA criteria and can hardly be considered APU (TIPAU) taken into account its main land use and rural occupation and their demographic and socio-indicators.

The parishes of UF de Alcácer (Sta. Maria do Castelo e Santiago) e Sta. Susana and UF de Moura (Sto. Agostinho e S. J. Baptista) e Santo Amador were selected to illustrate these situations. Both parishes have in common with the former 10 parishes the fact that they are the result of the 
administrative reorganisation of the Portuguese territory implemented in 2013. In these two examples, as in other situations, two former parishes where the headquarters of the municipality were located, merged with a third parish, labelled APR by TIPAU before 2014 .

Table 8. Illiteracy rate (\%) and employed population (\%) in localities with the municipal headquarters, and other territories belonging to APU (TIPAU) and Code 3 (DEGURBA) parishes.

\begin{tabular}{|c|c|c|c|c|c|c|c|c|}
\hline \multirow{3}{*}{ Parish } & \multicolumn{2}{|c|}{ Illiteracy Rate (\%) } & \multicolumn{6}{|c|}{ Employed Population (\%) } \\
\hline & \multirow[t]{2}{*}{ Locality } & \multirow{2}{*}{$\begin{array}{l}\text { Other } \\
\text { Territories }\end{array}$} & \multicolumn{3}{|c|}{ Locality } & \multicolumn{3}{|c|}{ Other Territories } \\
\hline & & & Primary & Secondary & Tertiary & Primary & Secondary & Tertiary \\
\hline Soure & 6.8 & 11.6 & 1.1 & 15.2 & 83.7 & 3.7 & 23.0 & 73.3 \\
\hline Mira & 4.4 & 6.8 & 4.2 & 20.0 & 75.7 & 6.1 & 27.0 & 67.0 \\
\hline $\begin{array}{l}\text { UF de Refojos de Basto, } \\
\text { Outeiro e Painzela }\end{array}$ & 4.4 & 9.1 & 1.7 & 23.9 & 74.4 & 4.5 & 40.0 & 55.5 \\
\hline Sertã & 5.0 & 8.4 & 2.3 & 23.1 & 74.6 & 3.9 & 30.8 & 65.3 \\
\hline Miranda do Corvo & 4.5 & 5.2 & 1.0 & 14.6 & 84.4 & 1.0 & 21.9 & 77.2 \\
\hline $\begin{array}{l}\text { UF de Bombarral e Vale } \\
\text { Covo }\end{array}$ & 3.7 & 6.9 & 3.5 & 20.1 & 76.4 & 10.7 & 26.0 & 63.3 \\
\hline Redondo & 8.1 & 12.9 & 11.6 & 21.5 & 66.9 & 34.0 & 18.6 & 47.5 \\
\hline $\begin{array}{l}\text { UF de Ferreira do } \\
\text { Alentejo e Canhestros }\end{array}$ & 10.1 & 15.3 & 11.6 & 14.2 & 74.2 & 38.3 & 22.9 & 38.7 \\
\hline $\begin{array}{c}\text { UF de Castro Verde e } \\
\text { Casével }\end{array}$ & 4.6 & 16.1 & 3.6 & 29.1 & 67.3 & 25.2 & 21.1 & 53.8 \\
\hline $\begin{array}{c}\text { UF de Aljustrel e Rio de } \\
\text { Moinhos }\end{array}$ & 5.2 & 17.3 & 2.8 & 31.0 & 66.2 & 17.5 & 38.4 & 44.1 \\
\hline
\end{tabular}

In spite of the inhabitant figures being between 5000 and 50,000, the population density of 10.2 and 30.7 inhabitants per sq.km, respectively, are significantly below the thresholds defined by the DEGURBA criteria (300 to 1500 inhabitants per sq.km). According to the other criterion established by DEGURBA, the parish of UF de Alcácer (Sta. Maria do Castelo e Santiago) e Sta. Susana includes only eight $1 \times 1$ sq.km grids with more than 300 inhabitants and the UF de Moura (Sto. Agostinho e S. J. Baptista) e Santo Amador contains six of those grids. Regarding the area of those territories, this means that only $0.9 \%$ of the territory of the first parish is covered by the said grids, and also only $2.1 \%$ of the territory of the second parish.

An analysis of the data of these two parishes shows the same patterns present in the former 10 parishes. The main localities, the administrative reason why it was labelled APU by the TIPAU, represent only $0.8 \%$ and $1.3 \%$ of the territory of the parishes. Regarding the artificialized surface of these parishes, it represents less than $2 \%$ of the whole territory of the parishes. The size of artificialized surfaces in the rest of the parish territories (excluding the main localities) are very low (1.2 and $0.6 \%$ ), since the main land uses are agricultural, forest and natural land, water bodies and wetlands (Figure 11B).

Concerning the socio-indicators, the proportion of the population resident in the locality where the municipal headquarters is located $(68.1 \%$ and $90.8 \%$ of the population live in $0.8 \%$ and $1.3 \%$ of the parish's territory, respectively for UF Alcácer do Sal and UF Moura), means that the remaining 31.9\% and $9.2 \%$ of the parish's population lives in the remaining vast extensions of the territories (881.2 and 283.8 sq.km, corresponding to $99.2 \%$ and $98.7 \%$ of the parish's territory, respectively). This percentage lives in very small villages/localities (Table 9), the largest containing no more than 200 to 399 inhabitants and most of them with less than 100 inhabitants. Significant percentages of the whole population $(4.8 \%$ and $4.4 \%)$ can be found living in residual places, in agricultural or natural environments and considerably distant from the municipal headquarters. 
Table 9. Number of other territories in APU (TIPAU) and Code 3 (DEGURBA) parishes, according to their population size.

\begin{tabular}{|c|c|c|c|c|c|c|c|c|}
\hline \multirow{2}{*}{ Parish } & \multirow{2}{*}{ Locality } & \multicolumn{6}{|c|}{ Other Territories } & \multirow{2}{*}{ Total } \\
\hline & & $800-999$ & $600-799$ & $400-599$ & 200-399 & 100-199 & 0-99 & \\
\hline $\begin{array}{c}\text { UF de Alcácer (Sta. Maria do Castelo } \\
\text { e Santiago) e Sta. Susana }\end{array}$ & 1 & & & & 5 & 3 & 18 & 27 \\
\hline $\begin{array}{c}\text { UF de Moura (Sto. Agostinho e S.J. } \\
\text { Baptista) e Santo Amador }\end{array}$ & 1 & & & & 1 & & 2 & 4 \\
\hline
\end{tabular}

The figures shown in Tables 10 and 11 illustrate how distinct the populations living in the locality or in the remaining territories are: the population in the urban centres/localities is younger and the ageing and dependency ratios are lower. Regarding illiteracy rates, the population living in urban centres/localities shows high values, but less than half of the values found in the remaining territories. The active population employed, according to economic sectors for the locality and for the remaining territories is distinctly unequal. Although figures are high, the percentages of the employed population in primary activities in the localities are well below the figures for the population living in the remaining territories, where percentages range from $26.8 \%$ and $44.6 \%$.

Table 10. Age groups (\%) and demographic indices in localities with the municipal headquarters, and other territories belonging to APU (TIPAU) and Code 2 (DEGURBA) parishes.

\begin{tabular}{|c|c|c|c|c|c|c|c|c|c|c|c|c|}
\hline \multirow{3}{*}{ Parish } & \multicolumn{6}{|c|}{ Age Groups (\%) } & \multicolumn{6}{|c|}{ Demographic Indexes } \\
\hline & \multicolumn{3}{|c|}{ Locality } & \multicolumn{3}{|c|}{ Other Territories } & \multicolumn{3}{|c|}{ Locality } & \multicolumn{3}{|c|}{ Other Territories } \\
\hline & 0-14 & $15-64$ & $\geq 65$ & 0-14 & $15-64$ & $\geq 65$ & AI & YI & ODR & AI & YI & ODR \\
\hline $\begin{array}{c}\text { UF de Alcácer (Sta. Maria } \\
\text { do Castelo e Santiago) e } \\
\text { Sta. Susana }\end{array}$ & 14.9 & 62.9 & 22.2 & 10.1 & 61.8 & 28.1 & 148.9 & 67.2 & 35.2 & 279.3 & 35.8 & 45.5 \\
\hline
\end{tabular}

Table 11. Illiteracy rate (\%) and employed population (\%) in localities with the municipal headquarters, and other territories belonging to APU (TIPAU) and Code 2 (DEGURBA) parishes.

\begin{tabular}{|c|c|c|c|c|c|c|c|c|}
\hline \multirow[b]{2}{*}{ Parish } & \multicolumn{2}{|c|}{ Illiteracy Rate (\%) } & \multicolumn{6}{|c|}{ Employed Population (\%) } \\
\hline & Locality & $\begin{array}{c}\text { Other } \\
\text { Territories }\end{array}$ & \multicolumn{3}{|c|}{ Locality } & \multicolumn{3}{|c|}{ Other Territories } \\
\hline $\begin{array}{c}\text { UF de Alcácer (Sta. Maria } \\
\text { do Castelo e Santiago) e Sta. } \\
\text { Susana }\end{array}$ & 9.4 & 17.3 & 10.1 & 18.6 & 71.3 & 26.8 & 17.2 & 55.9 \\
\hline
\end{tabular}

The conclusions that can be drawn by these last two examples is that inconsistencies and arguable classifications do not restrict themselves to a specific classification attributed by TIPAU or DEGURBA, but extend to the set of the given six classifications (APR, AMU and APU for TIPAU; Code 1, 2 and 3 for DEGURBA). Additionally, parishes like UF de Alcácer (Sta. Maria do Castelo e Santiago) e Sta. Susana (the largest parish in Portugal with 888.35 sq. $\mathrm{km}$ ) were classified the same way as parishes of cities in Lisbon and Oporto.

Other cases of parishes classified as urban by both classifications could be similarly presented. For example, a group of 10 parishes (UF de Caminha (Matriz) e Vilarelho; Tábua; UF de Ponte da Barca, Vila Nova de Muía e Paço Velho de Magalhães; UF de Constantim e Vale de Nogueiras; Armamar; Poiares (Santo André); UF de Santa Comba Dão e Couto do Mosteiro; UF de Oliveira de Frades, 
Souto de Lafões e Sejães; UF de Tarouca e Dálvares; Nelas), belonging to the same subset of the 98 (all of them designated as Code 3 for DEGURBA and, in contrast, APU for TIPAU) have similar characteristics to those above, except that they have less than 5000 inhabitants, show the same inconsistency-perhaps at a higher level—since they have a smaller population. All of them were also labelled as APU (TIPAU) because they partially or totally contain the locality where the headquarters of the municipality is located (the administrative criterion for TIPAU). However, the indicators for occupation and land use are quite similar to those 10 parishes seen above.

\section{Discussion}

The information and the results so far presented lead to the discussion of several issues concerning the classification of territories according to their degree of urbanisation. Four main points stand out and can be outlined as follows:

COS and CRUS are not suited for classifying the territory in terms of being or not being urban. Although COS can give the real extent of the artificialized territories, according to a specific classification scheme, this characteristic by itself does not enable us to conclude what the urban character of a place is. CRUS, in turn, as it is a planning tool, could, combined with other criteria, be a good indicator of the territorial expression of the urban. However, besides including oversized expansion areas (that can never be built upon) as an outcome of expectations perceived at specific land planning instances, this also includes the delimitation of human settlements of different sizes and hierarchical importance in the urban panorama of the country, making it difficult to classify the degree of urbanisation. At a more global scale, land use/land cover maps are not limited by national or other administrative nomenclature boundaries [58] and the way in which they are produced can be suitable for governments, nongovernmental organisations, and other stakeholders assisting in the development and implementation of environmental policies for a sustainable future [59], but the different methodological and technical approaches can also be locally relevant but globally inconsistent.

The territorial unit area classified both by DEGURBA and TIPAU is the parish (LAU2), the minimum administrative geographical level in Portugal. The usefulness of these administrative units is undeniable since they allow their inhabitants to benefit from a local administration and budgetary facility associated with their territory [60]. However, as seen throughout the research and supported by other studies [61], parishes are far from being homogeneous units; their own internal differences are often expressed through many essential aspects, such as a wide range of situations that vary from densely artificialized to natural landscapes, thus providing distinct land uses, degrees of occupation, population densities and, accordingly, urban or rural characters. In large cities and compact urban areas, parishes naturally tend to be homogeneous (in terms of urban land uses) since they constitute a part of the city's fabric. However, outside the large urban areas, the parish in Portugal consists of a territory which is quite heterogeneous (urban land uses and rural land uses, each with multiple associated land uses). This situation is enhanced by the changes in administrative boundaries, that frequently occur by decree, and causes statistical analysis impacts. The Modifiable Areal Unit Problem (MAUP) [30] and related studies [28], finds evidence here, when arbitrary modification of the analysis units are introduced, but the criteria for the classification remains the same. Assigning an urban character to an entire territory of a parish, which is often full of contrasts, biases the reading of the expression of the urban in the territory and therefore misinforms planning and territorial cohesion actions, and also seriously distorts the statistics provided to a wide spectre of official entities, the scientific community and the wider general public. In this respect, Hwang et al. [62] also question the homogeneity of the geographic area provided by the census output areas. Thus, as the necessity to classify territories according to their degrees of urbanisation is unquestionable, the data and the results presented illustrate that the parish is not the suitable unit to be classified in terms of its degree of urbanisation. Likewise, using LAU2 as a reference unit at the international level means that an assumption is made about the equivalent characteristics of these administrative areas among the various countries [63]. 
The nature of the criteria established by DEGURBA and TIPAU classifications, not in terms of their scientific accuracy or coherence from a theoretical perspective, but mainly concerning the results of their application to the reality of the territories, leads to a distorted overview of the urban. Several examples presented throughout the text reveal odd situations concerning the classification assigned and the physical and human aspects of a territory. DEGURBA criteria rely on (apparently objective) quantitative aspects, but there are a significant set of situations where the classification did not match such established criteria. The exercise carried out concerning just the matching of Portuguese continental parishes to the DEGURBA grid (population density and inhabitants thresholds)—which led to the lack of correspondence of hundreds of parishes-omits paradoxical situations. The most unexpected is the historical city of Guarda, the capital of the Portuguese "distrito" with the same name, which plays an important role in providing access to services, such as education, healthcare, justice and diversified commerce, for the surrounding areas (mainly rural) and which forms part of the regional urban network established in the spatial planning instruments. The parish that comprises almost the whole city, notwithstanding its 705.5 inhabitants per sq.km, was labelled Code 3. As for TIPAU, the quantitative criteria mixed with administrative issues (such as the extent of a locality or whether the place is where the headquarters of the municipality is located) is clearly responsible for many of situations where the classification attributed is questionable in terms of what is actually in the territory in terms of its urban character.

Several institutions which disseminate statistical information, including Statistics Portugal, Eurostat, OECD, use these classifications to measure and compare complex patterns of human settlements. Statistics Portugal presents several demographic and socio-economic indicators according to the TIPAU classification frame at the national and international level [64]. While the present study was being carried out, the OECD presented a report assessing, among other aspects, the quality of life considering the three levels of the degree of urbanisation [1]. Thus, as parishes were previously classified in a tripartite structure irrespective of their true urban or rural character as a whole, the information provided may be lacking in its propriety as has been shown in this paper. This point raises another question: the lack of convergence regarding national and international classifications, where such classifications are perhaps uncritically used to analyse, interpret and draw conclusions on issues concerning objective outcomes (wage and incomes, income and employment opportunities, educational attainment, health outcomes, etc.) or subjective perceptions (quality of life, life satisfaction and living standards, etc.).

Since the purpose of these classifications is to provide information for urban planning, for the studies which define public policies and for comparative analyses at the national and international levels, how can the inadequacies highlighted in this study be incorporated? How should the areas that represent different realities be compared? Returning to Bailey's work [19] concerning the importance of classification for the conceptualisation of complex phenomena, the key to a successful classification lies in the ability to ascertain the fundamental characteristics on which the classification is to be based.

\section{Conclusions}

This study has shown that the "map" of the urban is significantly distinct depending on the different official institutions that provide this information. The classification of the parish territorial unit in Portugal, (LAU2) according to the criteria of DEGURBA and TIPAU, can create an inaccurate perspective of the urban dimension from the national perspective and therefore have political, planning and management consequences for the territories which resulted from this process. A few arbitrary choices were made, which have needed to be discussed, and certain inaccuracies appear evident. Furthermore, the administrative reorganisation of the territory of the parishes (carried out in 2013), resulting in the amalgamation of various distinct territories, should have been a reason for reviewing the urban classification criteria by Statistics Portugal.

If the DEGURBA and TIPAU criteria are considered to form a valid basis, significant improvements are needed before submitting the results for validation by Member States: (i) some parishes have not 
been correctly classified; (ii) the weighting of the importance of the presence of municipal headquarters is too strong in the TIPAU classification (which may not make sense when this has a residual expression); (iii) a participatory classification involving the parish assembly is needed; (iv) a new revised parish map revision should be considered.

To promote equivalent access to essential goods and services in rural and urban areas, and therefore to achieve the desirable goal of territorial cohesion through the allocation of appropriate resources, a different and insightful approach to identifying what is urban is desirable.

Author Contributions: Conceptualization, Cristina Henriques, Alexandre Domingues and Margarida Pereira; Methodology, Cristina Henriques and Alexandre Domingues; Formal Analysis, Cristina Henriques and Alexandre Domingues; Investigation, Cristina Henriques, Alexandre Domingues and Margarida Pereira; Data Curation, Alexandre Domingues; Writing-Original Draft Preparation, Cristina Henriques and Alexandre Domingues; Writing, Review and Editing, Cristina Henriques; Visualization, Cristina Henriques; Supervision, Cristina Henriques; Project Administration, Cristina Henriques; Funding Acquisition, Cristina Henriques. All authors have read and agreed to the published version of the manuscript.

Funding: This research was funded by CIAUD-Research Centre for Architecture, Urbanism and Design, grant number UIDB/04008/2020.

Acknowledgments: The authors would like to thank DGT—Direção Geral do Território—for providing data concerning CRUS. The authors would also like to express their gratitude to Professor João Cabral for the valuable contributions on proofreading.

Conflicts of Interest: The authors declare no conflict of interest. The funders had no role in the design of the study; in the collection, analyses, or interpretation of data; in the writing of the manuscript, or in the decision to publish the results.

\section{References}

1. OECD/European Commission. Cities in the World: A New Perspective on Urbanisation; OECD Urban Studies; OECD Publishing: Paris, France, 2020. [CrossRef]

2. Merrifield, A. The Urban Question under Planetary Urbanization. Int. J. Urban Reg. Res. 2013, 37, 909-922. [CrossRef]

3. United Nations, Department of Economic and Social Affairs, Population Division. World Urbanization Prospects; United Nations: New York, NY, USA, 2019. [CrossRef]

4. European Union. Urban Europe. Statistics on Cities, Towns and Suburbs; Publications office of the European Union: Luxembourg, 2016. [CrossRef]

5. Brenner, N. Introduction: Urban Theory Without an Outside. In Implosions/Explosions towards a Study of Planetary Urbanization; Brenner, N., Ed.; Jovis: Berlin, Germany, 2014; pp. 14-35.

6. Robinson, J. Comparative Urbanism: New Geographies and Cultures of Theorizing the Urban. Int. J. Urban Reg. Res. 2016, 40, 187-199. [CrossRef]

7. Taubenböck, H.; Standfub, I.; Klotz, M.; Wurm, M. The Physical Density of the City Deconstruction of the Delusive Density Measure with Evidence from Two European Megacities. ISPRS Int. J. Geo-Inf. 2016, 5, 206. [CrossRef]

8. Antrop, M. Landscape Change and the Urbanization Process in Europe. Landsc. Urban Plan. 2004, 67, 9-26. [CrossRef]

9. Stewart, C.T. The Urban-Rural Dichotomy: Concepts and Uses. Am. J. Sociol. 1958, 64, 152-158. [CrossRef]

10. Inostroza, L.; Hamstead, Z.; Spyra, M.; Qhreshi, S. Beyond Urban-Rural Dichotomies: Measuring Urbanisation Degrees in Central European Landscapes Using the Technomass as an Explicit Indicator. Ecol. Indic. 2019, 96, 466-476. [CrossRef]

11. Wandl, A.; Nadin, V.; Zonneveld, W.; Rooij, R. Beyond Urban-Rural Classifications: Characterising and Mapping Territories-in-between across Europe. Landsc. Urban Plan. 2014, 130, 50-63. [CrossRef]

12. Iossifova, D.; Doll, C.; Gasparatos, A. Defining the Urban. Why Do We Need Definitions. In Defining the Urban. Interdisciplinary and Professional Perspectives; Routledge: London, UK, 2018; pp. 1-7.

13. Lefebvre, H. The Production of Space; Blackwell: Oxford, UK, 1991.

14. Holland, J. Complex Adaptive Systems. Daedalus 1992, 121, 17-30.

15. Batty, M.; Barros, J.; Alves, S. Cities: Continuity, Transformation and Emergence; UCL Working Papers Series; CASA: London, UK, 2004. 
16. Bloom, D.E.; Canning, D.; Fink, G.; Khanna, T.; Salyer, P. Urban Settlement: Data, Measures, and Trends. In Urbanization and Development: Multidisciplinary Perspectives; Jo Beall, B., Guha-Khasnobis, R.K., Eds.; Oxford University Press: Oxford, UK, 2010. [CrossRef]

17. Petts, J.; Owens, S.; Bulkeley, H. Crossing Boundaries: Interdisciplinarity in the Context of Urban Environments. Geoforum 2008, 39, 593-601. [CrossRef]

18. Weeks, J. Defining Urban Areas. In Remote Sensing of Urban and Suburban Areas; Rashed, T., Jürgens, C., Eds.; Springer Science+Business Media: Berlin/Heidelberg, Germany, 2010; Volume 10, pp. 181-192. [CrossRef]

19. Bailey, K.D. Typologies and Taxonomies: An Introduction to Classification Techniques; Sage University Paper Series on Quantitative Applications in the Social Sciences; SAGE: Thousand Oaks, CA, USA, 1994; Volume 47.

20. Dijkstra, L.; Poelman, H. A Harmonised Definition of Cities and Rural Areas: The New Degree of Urbanisation; European Comission: Brussels, Belgium, 2014.

21. OECD. Redefining "Urban": A New Way to Measure Metropolitan Areas; OECD Publishing: Paris, France, 2012. [CrossRef]

22. Eurostat. Methodological Manual on Territorial Typologies, 2018 ed.; Publications Office of the European Union: Luxembourg, 2019; p. 132. [CrossRef]

23. Satterthwaite, D. Urban Myths and the Mis-Use of Data That Underpin Them 1. In Urbanization and Development: Multidisciplinary Perspectives; Beall, J., Guha-Khasnobis, B., Kanbur, R., Eds.; Oxford University Press: Oxford, UK, 2010. [CrossRef]

24. Brenner, N.; Schmid, C. Towards a New Epistemology of the Urban? City 2015, 19, 151-182. [CrossRef]

25. Taubenböck, H.; Ferstl, J.; Dech, S. Regions Set in Stone-Delimiting and Categorizing Regions in Europe by Settlement Patterns Derived from EO-Data. ISPRS Int. J. Geo. Inf. 2017, 6, 55. [CrossRef]

26. Buettner, T. Urban Estimates and Projections at the United Nations: The Strengths, Weaknesses, and Underpinnings of the World Urbanization Prospects. Spat. Demogr. 2015, 3, 91-108. [CrossRef]

27. Georg, I.; Blaschke, T.; Taubenböck, H. Are We in Boswash yet? A Multi-Source Geodata Approach to Spatially Delimit Urban Corridors. ISPRS Int. J. Geo-Inf. 2018, 7, 15. [CrossRef]

28. Jiang, B.; Anders Brandt, S. A Fractal Perspective on Scale in Geography. ISPRS Int. J. Geo. Inf. $2016,5,95$. [CrossRef]

29. Gehlke, C.E.; Biehl, K. Certain Effects of Grouping upon the Size of the Correlation Coefficient in Census Tract Material. J. Am. Stat. Assoc. 1934, 29, 169-170. [CrossRef]

30. Openshaw, S. The Modifiable Area Unit Problem. In Concepts and Techniques in Modern Geography; GeoBooks: Norwich, UK, 1983; Volume 38.

31. Costa, H.; Almeida, D.; Vala, F.; Marcelino, F.; Caetano, M. Land Cover Mapping from Remotely Sensed and Auxiliary Data for Harmonized Official Statistics. ISPRS Int. J. Geo. Inf. 2018, 7, 157. [CrossRef]

32. Liu, X.; Ning, X.; Wang, H.; Wang, C.; Zhang, H.; Meng, J. A Rapid and Automated Urban Boundary Extraction Method Based on Nighttime Light Data in China. Remote Sens. 2019, 11, 1126. [CrossRef]

33. Zhou, Y.; Smith, S.J.; Zhao, K.; Imhoff, M.; Thomson, A.; Bond-Lamberty, B.; Asrar, G.R.; Zhang, X.; He, C.; Elvidge, C.D. A Global Map of Urban Extent from Nightlights. Environ. Res. Lett. 2015, 10, 2000-2010. [CrossRef]

34. Tenedório, J.A.; Rebelo, C.; Estanqueiro, R.; Henriques, C.D.; Marques, L.; Gonçalves, J.A. New Developments in Geographical Information Technology for Urban and Spatial Planning. In Technologies for Urban and Spatial Planning: Virtual Cities and Territories; IGI Global: Hershey, PA, USA, 2016; pp. 196-227. [CrossRef]

35. Sayer, A. Defining the Urban. GeoJournal 1984, 9, 279-284. [CrossRef]

36. Nicolau, R.; Cavaco, C. Automated Delimitation of Urban Areas Comprising Small-Sized Towns-Comparison of Two Methodologies Applied to Mainland Portugal. Environ. Plan. B Urban Anal. City Sci. 2018, 45, 180-201. [CrossRef]

37. INE-Instituto Nacional de Estatística. Administrative Division. Available online: https://www.ine.pt/ xportal/xmain?xpid=INE\&xpgid=ine_cont_inst\&INST=6251038\&xlang=pt (accessed on 3 September 2020).

38. Eurostat. Local Administrative Units. Available online: https://ec.europa.eu/eurostat/web/nuts/localadministrative-units (accessed on 1 October 2020).

39. INE-Instituto Nacional de Estatística. Tipologia de Áreas Urbanas. 2014. Available online: http://smi.ine.pt/ Versao/Download/10129 (accessed on 3 September 2020).

40. Eurostat. Degree of Urbanisation. Available online: https://ec.europa.eu/eurostat/web/degree-ofurbanisation/background (accessed on 1 October 2020). 
41. Hosseini, S.; Frank, L.; Fridgen, G.; Heger, S. Do Not Forget About Smart Towns: How to Bring Customized Digital Innovation to Rural Areas. Bus. Inf. Syst. Eng. 2018, 60, 243-257. [CrossRef]

42. Gibas, P.; Majorek, A. Analysis of Land-Use Change between 2012-2018 in Europe in Terms of Sustainable Development. Land 2020, 9, 46. [CrossRef]

43. Klimanek, T.; Filas-Przybyl, S. The Impact of the Applied Typology on the Statistical Picture of Population Ageing in Urban Areas in Poland-A Comparative Analysis. Stat. Transit. New Ser. 2019, 20, 135-152. [CrossRef]

44. Lorenzo-López, L.; Millán-Calenti, J.C.; López-López, R.; Diego-Diez, C.; Laffon, B.; Pásaro, E.; Valdiglesias, V.; Maseda, A. Effects of Degree of Urbanization and Lifetime Longest-Held Occupation on Cognitive Impairment Prevalence in an Older Spanish Population. Front. Psychol. 2017, 8, 1-9. [CrossRef] [PubMed]

45. Brink, M.; Schäffer, B.; Vienneau, D.; Pieren, R.; Foraster, M.; Eze, I.C.; Rudzik, F.; Thiesse, L.; Cajochen, C.; Probst-Hensch, N.; et al. Self-Reported Sleep Disturbance from Road, Rail and Aircraft Noise: Exposure-Response Relationships and Effect Modifiers in the SiRENE Study. Int. J. Environ. Res. Public Health 2019, 16, 4186. [CrossRef] [PubMed]

46. Froemelt, A.; Buffat, R.; Hellweg, S. Machine Learning Based Modeling of Households: A Regionalized Bottom-up Approach to Investigate Consumption-induced Environmental Impacts. J. Ind. Ecol. 2020, 24, 639-652. [CrossRef]

47. Medical Research Council. MRC-NIHR Methodology Research Programme Overview. Available online: https://mrc.ukri.org/funding/science-areas/methodology-research/overview/ (accessed on 1 October 2020).

48. Copernicus. CORINE Land Cover. Available online: https://land.copernicus.eu/pan-european/corine-landcover (accessed on 1 October 2020).

49. DGT-Direção-Geral do Território. Carta de Uso e Ocupação do Solo-2015. Available online: https://snig. dgterritorio.gov.pt/rndg/srv/por/catalog.search\#/search?anysnig=cos\&fast=index (accessed on 1 October 2020).

50. DGT-Direção-Geral do Território. Carta do Regime de Uso do Solo. Available online: https: //snig.dgterritorio.gov.pt/rndg/srv/por/catalog.search\#/search?resultType=details\&sortBy=referenceDateOrd\& anysnig $=$ crus\&fast=index\&_content_type $=$ json\&type $=$ dataset $\% 2$ Bor $\% 2 B s e r i e s \& f r o m=1 \& t o=20$ (accessed on 1 October 2020).

51. Ferreira, J.A.; Condessa, B.; Castro e Almeida, J.; Pinto, P. Urban Settlements Delimitation in Low-Density Areas-An Application to the Municipality of Tomar (Portugal). Landsc. Urban Plan. 2010, 97, 156-167. [CrossRef]

52. Swianiewicz, P.; Gendźwiłł, A.; Zardi, A. Territorial Reforms in Europe: Does Size Matter? Centre of Expertise for Local Government Reform: Brussels, Belgium, 2017.

53. Carranca, M.A.; Castro, N. Dinamica Dos Perimetros Urbanos Nos PDM Revistos Apos a Publicaçao Do PNPOT_Documento Técnico DGOTDU 9/2011; DGOTDU: Lisbon, Portugal, 2011.

54. INE-Instituto Nacional de Estatística. Sistema de Meta Informação. Available online: http://smi.ine.pt/ (accessed on 3 September 2020).

55. Eurostat. Glossary: Old-Age Dependency Ratio. Available online: https://ec.europa.eu/eurostat/statisticsexplained/index.php/Glossary:Old-age_dependency_ratio (accessed on 1 October 2020).

56. INE-Instituto Nacional de Estatística. Classificação Portuguesa Das Actividades Económicas Rev.3; Instituto Nacional de Estatística, I.P.: Lisbon, Portugal, 2007.

57. European Comission. NACE Rev. 2-Statistical Classification of Economic Activites in the European Community; Methodologies and Working Papers; Office for Official Publications of the European Communities: Luxembourg, 2008.

58. Manakos, I.; Tomaszewska, M.; Gkinis, I.; Brovkina, O.; Filchev, L.; Genc, L.; Gitas, I.Z.; Halabuk, A.; Inalpulat, M.; Irimescu, A. Comparison of Global and Continental Land Cover Products for Selected Study Areas in South Central and Eastern European Region. Remote Sens. 2018, 10, 1967. [CrossRef]

59. Grekousis, G.; Mountrakis, G.; Kavouras, M. An Overview of 21 Global and 43 Regional Land-Cover Mapping Products. Int. J. Remote Sens. 2015, 36, 5309-5335. [CrossRef]

60. Giménez, J.M.G.; Marques, T.V.D.S.; Aja, A.H. Procesos Urbanos Funcionales En Iberia: Una Aproximación a La Integración Del Territorio Urbano Más Allá de La Metropolización. Cuad. Geogr. 2020, 59, 93-128. [CrossRef]

61. Klimanek, T.; Filas-Przybył, S. The Statistical Picture of Population Aging in Towns of Wielkopolskie Province: TERYT and DE-GURBA Perspectives. J. Econ. Manag. 2020, 39, 41-61. [CrossRef] 
62. Hwang, C.S.; Hong, S.Y.; Hwang, T.K.; Yang, B. Strengthening the Statistical Summaries of Economic Output Areas for Urban Planning Support Systems. Sustainability 2020, 12, 5640. [CrossRef]

63. Jonard, F.; Lambotte, M.; Ramos, F.; Terres, J.-M.; Bamps, C. Delimitations of Rural Areas in Europe Using Criteria of Population Density, Remoteness and Land Cover; Office for Official Publications of the European Communities: Luxembourg, 2009.

64. INE-Instituto Nacional de Estatística. Retrato Territorial de Portugal; Instituto Nacional de Estatística, I.P.: Lisbon, Portugal, 2017.

Publisher's Note: MDPI stays neutral with regard to jurisdictional claims in published maps and institutional affiliations.

(C) 2020 by the authors. Licensee MDPI, Basel, Switzerland. This article is an open access article distributed under the terms and conditions of the Creative Commons Attribution (CC BY) license (http://creativecommons.org/licenses/by/4.0/). 